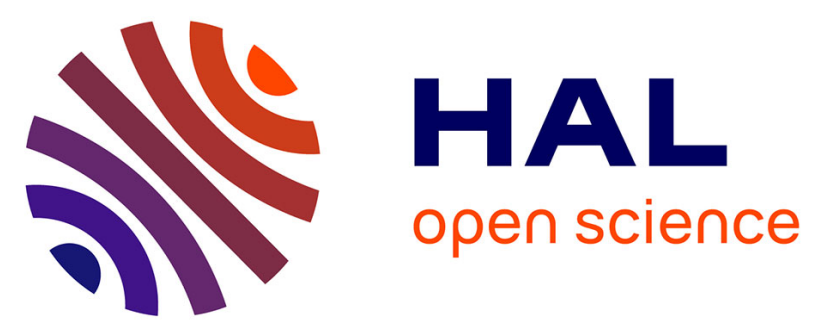

\title{
Long-term changes in alpine pedogenetic processes: Effect of millennial agro-pastoralism activities (French-Italian Alps)
}

Manon Bajard, Jérôme Poulenard, Pierre Sabatier, David Etienne, Francesco Ficetola, Wentao Chen, Ludovic Gielly, Pierre Taberle, Anne-Lise Develle, Pierre-Jérôme Rey, et al.

\section{To cite this version:}

Manon Bajard, Jérôme Poulenard, Pierre Sabatier, David Etienne, Francesco Ficetola, et al.. Longterm changes in alpine pedogenetic processes: Effect of millennial agro-pastoralism activities (FrenchItalian Alps). Geoderma, 2017, 306, pp.217-236. 10.1016/j.geoderma.2017.07.005 . hal-01681619

\section{HAL Id: hal-01681619 https://hal.science/hal-01681619}

Submitted on 7 May 2018

HAL is a multi-disciplinary open access archive for the deposit and dissemination of scientific research documents, whether they are published or not. The documents may come from teaching and research institutions in France or abroad, or from public or private research centers.
L'archive ouverte pluridisciplinaire $\mathbf{H A L}$, est destinée au dépôt et à la diffusion de documents scientifiques de niveau recherche, publiés ou non, émanant des établissements d'enseignement et de recherche français ou étrangers, des laboratoires publics ou privés.

\section{다(1)(2)}

Distributed under a Creative Commons Attribution - ShareAlikel 4.0 International 


\title{
Long-term changes in alpine pedogenetic processes: Effect of millennial agro-pastoralism activities (French-Italian Alps)
}

\author{
Manon Bajard ${ }^{\mathrm{a}, *}$, Jérôme Poulenard ${ }^{\mathrm{a}}$, Pierre Sabatier ${ }^{\mathrm{a}}$, David Etienne ${ }^{\mathrm{b}}$, Francesco Ficetola ${ }^{\mathrm{c}, \mathrm{d}}$, \\ Wentao Chen ${ }^{c}$, Ludovic Gielly ${ }^{c}$, Pierre Taberlet ${ }^{c}$, Anne-Lise Develle ${ }^{a}$, Pierre-Jérôme Rey ${ }^{a}$, \\ Bernard Moulin $^{\mathrm{e}}$, Jacques-Louis de Beaulieu ${ }^{\mathrm{f}}$, Fabien Arnaud ${ }^{\mathrm{a}}$ \\ ${ }^{\text {a }}$ EDYTEM, Université Savoie Mont-Blanc, CNRS Pôle Montagne, 73376 Le Bourget du Lac, France \\ b UMR INRA 42 CARRTEL, Université Savoie Mont-Blanc, 73376 Le Bourget-du-Lac, France \\ ${ }^{c}$ Laboratoire d'Ecologie Alpine, CNRS UMR 5553, Université Joseph Fourier, 38041 Grenoble Cedex 9, France \\ d Department of Biosciences, Università degli Studi di Milano, Milan 20133, Italy \\ e Centre d'Archéologie Préhistorique du Rhône aux Alpes, F 26000 Valence, France \\ ${ }^{\mathrm{f}}$ Aix Marseille Université, CNRS, IRD, IMBE, UMR $7263 \&$ 237, Aix-en-Provence, France
}

\section{A R T I C L E I N F O}

Keywords:

Lake sediments

Pedogenesis

Erosion

Geochemistry

Paleosols

Human activities

\begin{abstract}
A B S T R A C T
Human activities are known to modify soil properties; however, the associated modifications to soil processes are poorly documented, as they must be studied over long time scales. Lake Verney, which is on the Italian side of the Petit Saint-Bernard Pass in the French-Italian Alps (2188 $\mathrm{m}$ a.s.l.) provides a sediment record of the last 11,000 cal. yrs BP. Analysis of multiple proxies within this sediment sequence, including sedimentological characteristics, mineral geochemistry (as determined using XRF and extractable Fe fractions), pollen and nonpollen palynomorphs (NPPs) and sediment DNA (sedDNA) analysis, is compared with analyses of current soils and paleosols within this mountain ecosystem in order to understand the main drivers of long-term pedogenesis. We performed principle component analysis on both the sediment proxies and the soil geochemical properties to identify different sediment endmembers that reflect different types of soil horizons, mainly stagnic and spodic. These horizons are characteristic of specific soil processes and their associated land uses.

During the first part of the Holocene, a decrease in the carbonate fraction in the sediment reflects the loss of carbonate material from soils that occurred as early as postglacial vegetation became established. The migration of Fe-complexes until 6000 cal. yrs BP indicates the development of Podzols in the catchment. The first signs of human land use are detected at 4300 cal. yrs BP according to analyses of sedDNA and NPPs. Increases in the input of terrestrial organic matter, associated with forest clearance suggests degradation of the surface horizons of the Podzols. Erosion increased during the Roman Period due to sheep grazing. Then, while erosion was still increasing, Podzols developed into Stagnosols after the Middle Ages with cow grazing which is consistent with the current functioning of the soils. The history of the paleosols and archaeological stratigraphy within the study area confirm the model of soil evolution inferred from the lake sediments and allow us to characterize the human-induced "metapedogenetic phase" of the evolution of the soil cycle. Anthropo-pedogenesis may define the development of soils during the Anthropocene. The main consequence of this change in the functioning of the soils is a reduced sequestration of soil carbon.
\end{abstract}

\section{Introduction}

Soils support multiple ecosystem services that are essential for life, such as food supply and water storage or for climate regulation, such as carbon sequestration (e.g., Daily et al., 1997; Adhikari and Hartemink, 2016). Because soils are a non-renewable resource over human time- scales (Vanwalleghem et al., 2017), the potential of provided services can be threatened by human activities that trigger erosion and land degradation (Oldeman, 1994; Sabatier et al., 2014; Vanwalleghem et al., 2017). In Europe, the cost of soil degradation has been estimated to be 38 billion $€$ per year (COM EU, 2006). The worldwide loss of carbon due to land use changes corresponds to more than

\footnotetext{
The data reported in this paper on the sedimentary sequence, including the age model, the loss on ignition, the grain-size distribution and the geochemistry, are deposited on PANGAEA: https://doi.pangaea.de/10.1594/PANGAEA.878058.

* Corresponding author.

E-mail address: manon.bajard@univ-smb.fr (M. Bajard).
} 

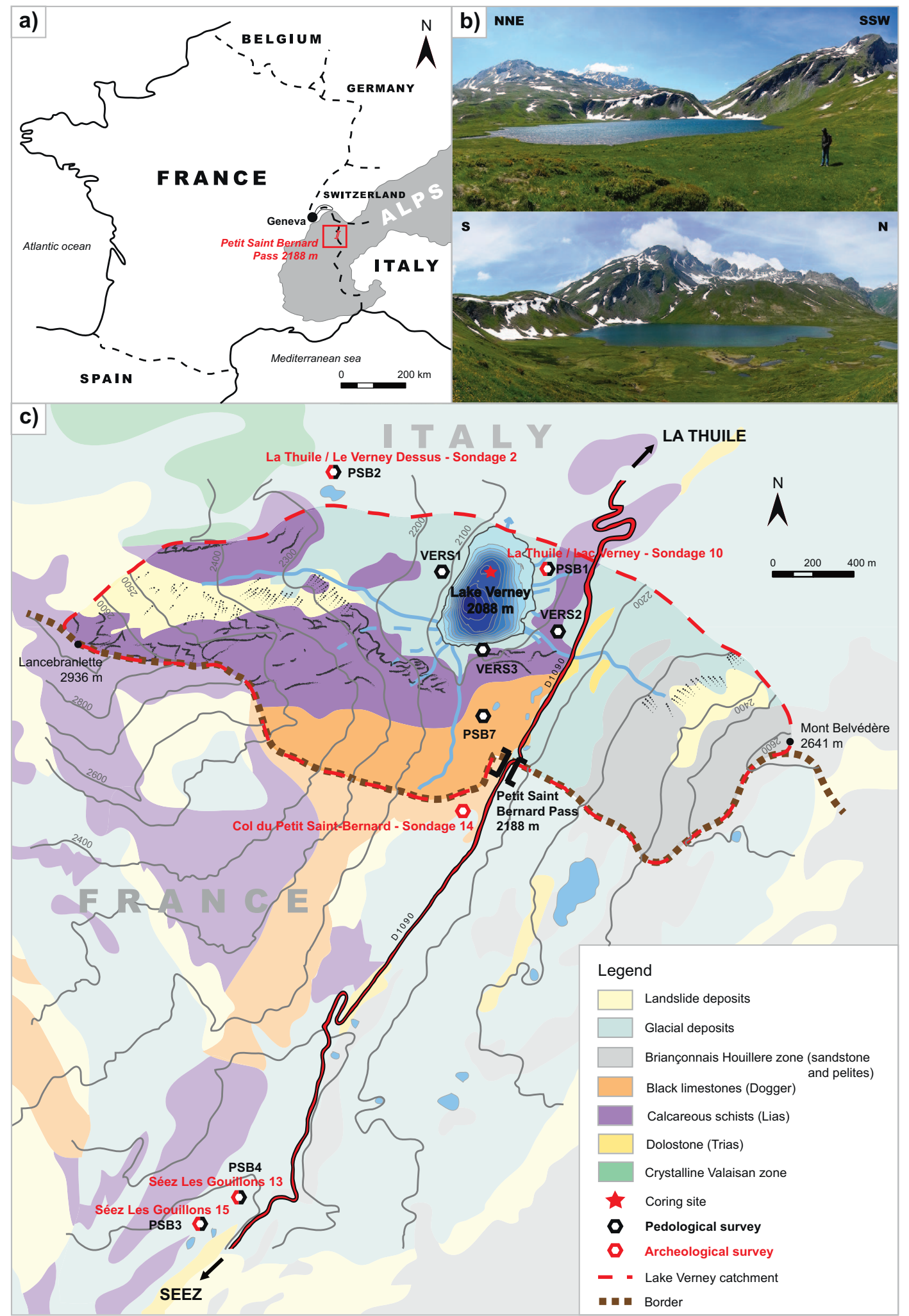

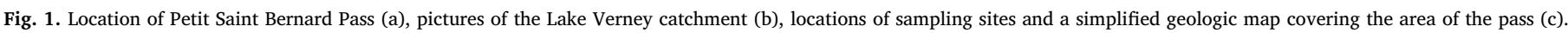
Abbreviations: LTH $=$ La Thuile.

one billion t. $\mathrm{yr}^{-1}$ since the 1960s (Le Quéré et al., 2016). However, considering the lack of knowledge concerning soil functioning, no regulatory measures have yet been established to protect soils (Puydarrieux et al., 2016). This lack is related to the complexity of pedogenesis and the feedbacks between erosion, soil properties, vegetation and agricultural management (Johnson and Watson-Stegner, 1987; Richter, 2007; Vanwalleghem et al., 2017), which have strongly varying response times.

Soils form slowly from the weathering of rocks and the incorporation of organic matter and are mixed and affected by vertical and 
horizontal transfers due to hydrological fluxes, bioturbation, slopes, etc. Soils thus depend on soil-forming factors defined by Jenny in 1941, namely, climate, organisms, relief, parent material and time. These factors were originally described for natural soil evolution.

The role of humans in soil evolution has long been neglected (Yaalon and Yaron, 1966; Richter, 2007). However, recent studies based on paleo-records that have yielded reconstructions of both soil evolution and human activities over long-term perspectives have demonstrated the importance of the human factor in pedogenesis (Bajard et al., 2017). Metapedogenetic phases were introduced by Yaalon and Yaron (1966) to define the changes in both pedogenetic processes and soil properties that are induced by humans.

Soil erosion must be considered within a long historical context in order to better understand the current drivers of soil degradation processes and their consequences for ecosystem functioning (Trimble and Mendel, 1995; Vanwalleghem et al., 2017).

During the last few decades, several studies have noted the potential of lake sediments to record physical erosion (Giguet-Covex et al., 2011; Simonneau et al., 2013; Sabatier et al., 2014; Bajard et al., 2016; Arnaud et al., 2016), changes in the degree of soil weathering (Dearing et al., 2001; Arnaud et al., 2012; Brisset et al., 2013; Bajard et al., 2017), pedogenetic processes (Mourier, 2008; Mourier et al., 2008; Giguet-Covex et al., 2011; Malkiewicz et al., 2016; Hošek et al., 2017), and the progressive and regressive phases of pedogenesis (Brisset et al., 2013; Malkiewicz et al., 2016; Bajard et al., 2017). Lakes sediments indeed store soil particles obtained from catchment fluxes and erosion triggered by human activities and/or climatic changes that correspond to soil development at the date of storage, providing a record of their evolution. Changes induced by erosion will depend on the characteristics of the soil profile, and thus into early pedogenetic processes. Few studies on soil evolution deciphered from lake sediments succeed in making accurate observations during the Anthropocene (Mourier et al., 2008; Giguet-Covex et al., 2011; Malkiewicz et al., 2016) because, among other factors, catchments drain the soil landscape diversity (Dreibrodt and Wiethold, 2015). It is necessary to understand the interdependence of landscape history (i.e., vegetation changes, human activities), soil evolution and erosion to sort the main forcing factors and their consequences on the agro-ecosystem to adapt its future management and ensure its sustainability.

Located in the Northwestern Alps, the Petit Saint-Bernard Pass area marks currently the border between France and Italy. Archaeological surveys and paleo-environmental studies enable the reconstruction of the landscape evolution and occupation phases around this pass. The oldest occupation phases were evident since the Neolithic period, and occurred mainly during the early Bronze period ( $c a .4000$ cal. yrs BP), the late Bronze period ( $3000 \mathrm{cal}$. yrs BP) and then in the Roman and Medieval periods (Crogiez-Petrequin, 2006; Leveau and Segard, 2006; Miras et al., 2006; Talon, 2006; Rey et al., 2014). Paleosols and archaeological stratigraphy indicated different occupation phases and recurrences within different soil horizons. Thus, we have an ideal site where human activities are well-documented, to assess their effects on soil evolution. Pollen and subfossil chironomid analysis from seven peat bog records collected around the pass at elevations ranging from 1850 to $2345 \mathrm{~m}$ a.s.1., indicate that changes in the landscape and climate occurred throughout the Holocene (Millet et al., 2008; Miras et al., 2006), but do not permit characterization of the effects of human activities on soil erosion dynamics. In this context, we studied the sediments from the largest lake on the Italian side, Lake Verney, to reconstruct, past soil evolution and human activities throughout the Holocene, using multiproxy lake sediment archives and present-day soil analysis. Data derived from paleosols (Moulin and Rey, 2008; Rey et al., 2014), charcoals (Talon, 2006) and archaeology (e.g., Rey and Moulin, 2006; Rey et al., 2014) then allowed us to validate and complete the Lake Verney sediment record and provide a complete soil evolution at the landscape scale. Finally, we integrated this evolution into the evolution cycle of the ecosystem.

\section{Materials and methods}

\subsection{Study site}

The Petit Saint Bernard Pass (2188 m a.s.1.) is located in the Western Alps, on the French-Italian border (Fig. 1-a), and it separates the villages of Séez in the Tarentaise valley (France) and La Thuile in the Aoste valley (Italy). On the Italian side of the pass, Lake Verney (2088 m a.s.l.) has a surface of $0.2 \mathrm{~km}^{2}$ and a maximum depth of $21 \mathrm{~m}$. The lake is fed by three main streams that flow from the south. Its catchment covers an area of $3.5 \mathrm{~km}^{2}$ and rises up to $2900 \mathrm{~m}$ a.s.l. According to the weather observation network of the alpine massif (ROMMA), the mean temperatures at the pass range from $-3.4{ }^{\circ} \mathrm{C}$ in winter to $9.7^{\circ} \mathrm{C}$ in summer (these values represent averages for 2014-2016). Snow covers the area from November to June, and the lake is ice-covered during winter. The western part of the catchment is underlain by Jurassic calcareous schists (Lias) and black limestones (Dogger). The eastern side of the pass is characterized by sandstone and pelites of the Briançonnais Houillere zone (Fig. 1-c). There are currently no trees in the catchment. Around the lake, grazed grasslands are dominated by matgrass and thufurs and are punctuated with Vaccinium myrtillus and V. uliginosum and several wetlands (Fig. 1-b). The current upper tree line (mainly Picea abies) is situated at approximately $1950 \mathrm{~m}$ a.s.l. on both sides of the pass. Anthracological analysis indicated an upper tree line of Pinus cembra between 2300 and $2500 \mathrm{~m}$ before human clearing (Talon, 2006). Fire episodes were recorded regularly in soils, suggesting that pasture activities occurred continuously until the present. Several remains of pastures structures were identified, mainly for cattle farming, in addition to Roman buildings situated along the Roman road that crossed the pass (Leveau and Segard, 2006; Rey et al., 2014). Surveys and pedo-sedimentary profiles performed on a $250-\mathrm{km}^{2}$ area covering both sides of the pass for archaeological analysis showed specific soil patterns above $1900 \mathrm{~m}$, with mainly Stagnosols and sparse Podzols (Moulin and Rey, 2008; Rey et al., 2014).

\subsection{Soil sampling}

An archaeological and pedo-sedimentary survey was performed between 2003 and 2007 in the area of the Petit Saint-Bernard Pass (Moulin and Rey, 2008; Rey et al., 2014) within the framework of the Interreg III A 2003-2006 project. We used anew the 5 profiles from this earlier study that are closest to the pass (LTH/Lac Verney - Sondage 10, LTH/Le Verney Dessus - Sondage 2, Séez - Les Gouillons 13, Séez - Les Gouillons 15 and PSB7; the names of these profiles are simplified to PSB1, PSB2, PSB4 and PSB3, respectively) for soil analyses (Fig. 1-c). We sampled three new profiles on each side of the lake: VERS1, VERS2 and VERS3. PSB1 (2100 m a.s.1.) is located north of Lake Verney. PSB2 (2262 m a.s.l.) is located near Lake Verney Dessus, in the northern part of the Lake Verney catchment. VERS 1 and VERS 2 are located on either side of the lake; VERS3 is to the south of the lake. PSB7 is located on the flat area west of the pass on the Italian side. PSB4 and PSB3 (2000 m a.s.l.) are situated on the French side of the pass. Soil profiles were described with color, texture, structure and $\mathrm{HCl}$ effervescence test. The FAO (Food and Agriculture Organization) soil classification (WRB FAO, 2014) and the Guidelines for soil description (FAO, 2006) were used for horizon and soil denominations. At least one sample was collected per horizons and sieved to $2 \mathrm{~mm}$ for further laboratory analyses.

\subsection{Sediment sequence and chronology}

\subsubsection{Coring}

Two coring missions were undertaken to retrieve sediments from the lake Verney in autumn 2012 and winter 2013. Short gravity cores were taken in 2012 from a small boat, and three longer sections (VER13-01, 02 and 03) that are approximately $2.4 \mathrm{~m}$ each in length 
were retrieved in 2013 from the ice-covered surface of northern flat part of the lake $\left(45^{\circ} 41^{\prime} 19.8^{\prime \prime} \mathrm{N}, 6^{\circ} 52^{\prime} 57.06^{\prime \prime} \mathrm{E}\right)$ at a depth of $15 \mathrm{~m}$ using an Uwitec piston coring device. The deepest part of the lake was avoided regard to rock landslides south of the lake. The cores were split into two halves. Each half was described in detail, and pictures were taken with a 20 -pixel. $\mathrm{mm}^{-1}$ resolution. The lithological description of the cores allowed the identification of different sedimentary units. A composite profile VER13-I was built using XRF-correlation from the three sediment sections obtained during the 2013 coring mission (the IGSN codes IEFRA05GT, IEFRA05GU and IEFRA05GV correspond to VER13-01, VER13-02 and VER13-03, respectively; IGSN codes refer to an open international database, www.geosamples.org). Data from a short gravity core (VER12-P4) obtained in 2012 (IGSN code: IEFRA00BU) were included to provide a well-preserved water-sediment interface.

\subsubsection{XRF core scanner}

The relative contents of major elements were analyzed by X-ray fluorescence (XRF) at high resolution (1 mm sampling step) on the surface of the sediment core with an Avaatech Core Scanner (EDYTEM Laboratory, CNRS-Université Savoie Mont-Blanc). The X-ray beam was generated with a rhodium anode and a $125-\mu \mathrm{m}$ beryllium window, which allows a voltage range of 7-50 kV and a current range of 0-2 mA. The split core surface was first covered with a $4-\mu \mathrm{m}$-thick Ultralene film to avoid contamination and desiccation of the sediment. The element intensities were expressed in counts per second (cps). The geochemical data were obtained with different settings according to the elements analyzed. These settings were adjusted to $10 \mathrm{kV}$ and $2 \mathrm{~mA}$ for $20 \mathrm{~s}$ to detect $\mathrm{Si}, \mathrm{Ca}, \mathrm{Al}, \mathrm{Fe}, \mathrm{Ti}, \mathrm{K}, \mathrm{Mn}$, and S. For heavier elements (i.e., $\mathrm{Sr}, \mathrm{Rb}$, $\mathrm{Zr}, \mathrm{Br}$, and $\mathrm{Pb}$ ), measurements were performed at $30 \mathrm{kV}$ and $1.2 \mathrm{~mA}$ for $80 \mathrm{~s}$.

\subsubsection{Grain-size distribution}

The grain-size distribution of the sediment was determined at high resolution, every $1 \mathrm{~cm}$, using a Malvern Mastersizer 2000G laser particle sizer. Ultrasonics were used to dissociate mineral particles and to avoid their flocculation. Results of the grain-size distribution were processed with MATLAB software and presented as a contour plot with a color scale according to the percentage abundance of particles for each grain-size class.

\subsubsection{Sedimentary environmental DNA (sedDNA)}

To reconstruct past vegetation and the nature of herds (i.e., cows or sheep) by DNA analysis, we sampled 55 slices of 2.5 to 3 -cm thickness covering the whole sediment core, following the strict laboratory precautions described in Giguet-Covex et al. (2014). For each sediment slice, we mixed $15 \mathrm{~g}$ of sediment with $15 \mathrm{ml}$ of saturated phosphate buffer (Na2HPO4; $0.12 \mathrm{M} ; \mathrm{pH} \approx 8$ ) for $15 \mathrm{~min}$. The mixture was then centrifuged $(10 \mathrm{~min}$ at $10,000 \mathrm{~g}) .12 \mathrm{ml}$ of the resulting supernatant were transferred to Amicon ${ }^{\circledR}$ Ultra-15 $10 \mathrm{~K}$ Centrifugal Filter Devices (Millipore) and centrifuged ( $20 \mathrm{~min}$ at $4000 \mathrm{~g}$ ) for sedDNA concentration. $400 \mu \mathrm{l}$ of the resulting concentrate was kept as starting material for DNA extraction using the NucleoSpin ${ }^{\circledR}$ Soil kit (Macherey-Nagel) (Taberlet et al., 2012). Four extraction controls were performed. Mammal and plant DNA was amplified with the primer pair P007, following the protocol described in Giguet-Covex et al. (2014). In addition to extraction controls, we also performed three PCR controls, containing PCR mix but no DNA template. Four PCR positive controls were also performed, each of which contained $0.18 \mathrm{ng}$ of DNA extracted from a marsupial (Didelphis marsupialis), that is not found in Europe. All samples and controls were amplified in 12 replicated PCRs (Ficetola et al., 2015). Sequencing was performed by $2 \times 125$ bp pair-end sequencing on an Illumina HiSeq 2500 platform, which returned $21,192,000$ reads.

DNA sequences were filtered using the OBITOOLS software (Boyer et al., 2016), as described in Pansu et al. (2015). Sequences were assigned to the relevant taxa by comparing them with global databases of mammal and plant sequences that were generated from EMBL using the ecoTag program. For mammals, we only kept sequences with a match $>97 \%$ with a mammal genus. For plants, we focused on two species characteristic of the study area (pine: Pinus sp. and spruce: Picea sp.), and we only considered sequences with a match $>97 \%$ with the sequences of these species. The full set of sedDNA results will be published in a subsequent study (Chen et al. in prep.). In sedDNA studies, false detections (i.e., sporadic detections of absent species) are possible. We thus only considered species confirmed by multiple PCR analyses performed on the same sample, whereas we discarded sequences detected with $<5$ reads in a given PCR replicate, and sequences frequently detected in the controls (human and pig).

\subsubsection{Pollen and non-pollen palynomorphs (NPPs)}

Following the same sampling that of sedDNA, 51 subsamples of approximately $1 \mathrm{~cm}^{3}$ were prepared for pollens and non-pollens palynomorphs analysis, using the standard procedure described by Faegri and Iversen (1989). Lycopodium clavatum tablets were added to each subsample (Stockmarr, 1971) in order to calculate the concentration of NPPs. They were counted following the procedure described by Etienne and Jouffroy-Bapicot (2014) and are expressed as accumulation rates $\left(\right.$ no $\left.\mathrm{cm}^{-2} \cdot \mathrm{yr}^{-1}\right)$. Their ecological interpretation in term of agro-pastoral activities and OM origin follows the work of Doyen and Etienne (2017). Non-arboreal pollen (NAP) was expressed as a percentage of the total pollen.

\subsubsection{Chronology}

The chronology of the Lake Verney sediment sequence is based on nine ${ }^{14} \mathrm{C}$ measurements performed on terrestrial plant macroremains, as well as short-lived radionuclide measurements $\left({ }^{210} \mathrm{~Pb}\right.$ and $\left.{ }^{137} \mathrm{Cs}\right)$ to date the latest century. AMS radiocarbon dates were performed by accelerator mass spectrometer (AMS) at the Poznan Radiocarbon Laboratory and at the Laboratoire de Mesure 14C (LMC14) ARTEMIS at the CEA (Atomic Energy Commission) Institute of Saclay (Table 1 ). The ${ }^{14} \mathrm{C}$ ages were converted to 'calendar' years using the IntCal13 calibration curve (Reimer et al., 2013). Short-lived radionuclide were measured on the

Table 1

Radiocarbon ages for Lake Verney sediment sequence.

\begin{tabular}{|c|c|c|c|c|c|c|}
\hline Sample name & Lab. code & Depth (mm) & Sample type & Age (BP) & Min. age (cal. BP) & Max. age (cal. BP) \\
\hline VERNEY1 & Poz-73372 & 393 & Wood and twigs & $8000 \pm 50$ & 8656 & 9010 \\
\hline VER13-1 & SacA 38343 & 548 & Plant macroremains & $875 \pm 30$ & 726 & 907 \\
\hline VERNEY2 & Poz-73373 & 753 & Herbs, twigs and moss & $4615 \pm 35$ & 5145 & 5465 \\
\hline VER13-02A-88 & SacA 32338 & 1048 & Plant macroremains & $2100 \pm 35$ & 1989 & 2287 \\
\hline VERNEY3 & Poz-73374 & 1213 & Herbs, twigs and moss & $3350 \pm 35$ & 3481 & 3687 \\
\hline VERNEY4 & Poz-73375 & 1353 & Herbs, twigs and moss & $3940 \pm 50$ & 4241 & 4521 \\
\hline VER13-02B-61 & SacA 32339 & 1748 & Plant macroremains & $8890 \pm 45$ & 9793 & 10,188 \\
\hline VER13-02B-96 & SacA 32340 & 2108 & Plant macroremains & $9725 \pm 50$ & 10,876 & 11,240 \\
\hline VER13-3 & SacA 38345 & 2383 & Plant macroremains & $9780 \pm 60$ & 10,905 & 11,315 \\
\hline
\end{tabular}


top of the sediment sequence at the Modane Underground Laboratory (LSM) by gamma spectrometry, using high-efficiency, very low-background, well-type Ge detectors (Reyss et al., 1995). The isotope ${ }^{137} \mathrm{Cs}$ was accidentally introduced into the environment at the end of the 1950 s as by-product of atmospheric nuclear weapons tests (peak at AD 1963). The Chernobyl accident in 1986 also dispersed ${ }^{137} \mathrm{Cs}$ into the northern atmosphere (Appleby et al., 1991). ${ }^{210} \mathrm{~Pb}$ excess $\left({ }^{210} \mathrm{~Pb}_{\mathrm{ex}}\right)$ results in the disintegration of ${ }^{226} \mathrm{Ra}$ of rocks into ${ }^{222} \mathrm{Rn}$ which disintegrates, in gas form, in ${ }^{210} \mathrm{~Pb}_{\mathrm{ex}}$ in the atmosphere and deposited in the lake. It was calculated in the sediment as the difference between total ${ }^{210} \mathrm{~Pb}$ (mixing of erosion and atmospheric deposits) and ${ }^{226} \mathrm{Ra}$ activity (Goldberg, 1963). ${ }^{226} \mathrm{Ra}$ activity is assuming equivalent to ${ }^{210} \mathrm{~Pb}$ activity of sediments triggered by erosion. Then, we used the Constant Flux/Constant Sedimentation (CFCS) model and the decrease in ${ }^{210} \mathrm{~Pb}_{\mathrm{ex}}$ to calculate the sedimentation rates. The uncertainty of sedimentation rates obtained by this method was derived from the standard error of the linear regression of the CFCS model. The age-depth model was then generated using R software and the R code package 'Clam' version 2.2 (Blaauw, 2010).

\subsection{Soil and sediment analysis}

\subsubsection{Loss on ignition}

Loss on ignition (LOI) analysis was performed on both the soil samples and sediments, following a continuous $1 \mathrm{~cm}$ sampling step all along the sediment sequence and every $3 \mathrm{~cm}$ using the sampling of DNA, pollens and NPPs analysis to estimate organic matter (OM) and carbonate content following the procedure described in Heiri et al. (2001). OM content was measured on dried sediment after $4 \mathrm{~h}$ at $550{ }^{\circ} \mathrm{C}$ in an oven, then carbonate content was measured after $2 \mathrm{~h}$ at $950^{\circ} \mathrm{C}$.

\subsection{2. $P$-XRF mineral geochemistry}

A portable ED-XRF spectrometer (S1 TITAN Bruker) was used to measure the major elements, which were expressed as relative percentages of oxides. Analysis of both gently crushed soil and sediment samples was performed through a $4-\mu \mathrm{m}$-thick Ultralene film in a 32 mm-diameter plastic cup. The samples were triplicated and analyzed over $60 \mathrm{~s}$ using the GeoChem Standard instrument's internal calibration mode (Shand and Wendler, 2014). The organic matter content that was deduced from the LOI at $550{ }^{\circ} \mathrm{C}$ was added to the sum of all major and trace elements. Consequently, the elemental results were brought to $100 \%$ less the OM percent to overcome the closed sum effects that are linked to OM variations (Baize, 2000). The standard deviations of the replicates were lower than the instrument errors, which were thus conserved as measurement uncertainties. The total contents of $\mathrm{Fe}$ and $\mathrm{Al}\left(\mathrm{Fe}_{\mathrm{Tot}}\right.$ and $\left.\mathrm{Al}_{\text {Tot }}\right)$ were estimated from $\mathrm{Fe}_{2} \mathrm{O}_{3}$ and $\mathrm{Al}_{2} \mathrm{O}_{3}$ contents, respectively.

\subsubsection{Extractable fractions}

To identify pedogenetic compounds specific to Podzol spodic horizons in both the soil and sediment samples, we quantified the amount of secondary mineral phases containing $\mathrm{Fe}, \mathrm{Al}$ and Si. Secondary Febearing phases were extracted from PSB1, PSB2, PSB3, PSB4 and PSB7 and secondary Fe-, Al- and Si-bearing were extracted from VERS1 and VERS2, and from 38 samples (each $1 \mathrm{~cm}$ thick) taken from the sediment core. For PSB1, PSB2, PSB3, PSB4 and PSB 7, the secondary Fe-bearing phase were extracted with three solutions of dithionite citrate, acid ammonium oxalate and $0.1 \mathrm{M} \mathrm{Na}$ pyrophosphate to quantify the crystalline, amorphous and organic-bound fractions in the samples, respectively (McKeague et al., 1971). For VERS1 and VERS2 and the sediment samples, $\mathrm{Al}, \mathrm{Fe}$ and $\mathrm{Si}$ were extracted only using an acid ammonium oxalate solution (Tamm, 1922). All of the extracts were then analyzed by ICP-AES. Soil $\mathrm{pH}$ was measured with a 1:5 soil-water ratio.

\subsection{Statistical analysis}

Principal component analysis (PCA) was performed on two sedimentary datasets that corresponded to the sampling strategy used for sedDNA, pollen and NPPs (3-cm-thick samples) and to the sampling strategy used for selective extraction (1-cm-thick-samplies), as well as on the soil geochemical parameters. PCA was used to assess the relationships between the elemental variations, human activities and soil dynamics in the catchment (Sabatier et al., 2010). Analyses were performed using R 2.13.1 (R Development Core Team, 2011).

\section{Results}

\subsection{Soil characterization}

Apart from Cambisols, Leptosols, Regosols and sparse Podzols, the current soils of the Petit-Saint Bernard Pass area, at elevations between 1800 and $2700 \mathrm{~m}$ are mainly related to Stagnosols (Moulin and Rey, 2008).

Regosols, represented by VERS3, were identified in the south part of Lake Verney on black limestone (Fig. 1-c). They are thin, and only the coarse elements effervesce with $\mathrm{HCl}$ acid solution. $\mathrm{pH}$ is high ( $\mathrm{pH}=7.1)$. No horizons were distinguished in these soils but they received sediments from slope deposits. Thus, they may also develop on the upper slopes of the catchment, locally as Leptosols and Cambisols.

Stagnosols were found around the lake (VERS1, VERS2), within the pass (PSB7 but also Séez - Col du Petit Saint-Bernard - Sondage 14) and on the Italian side of the pass below the lake catchment near Plan Veyle at an elevation of $2000 \mathrm{~m}$ (Rey et al., 2014). They are characterized by low $\mathrm{pH}$ (4.5) and low organic matter content in the mineral horizons (Fig. 2-a). Two types of mineral horizons, albic horizons in the subsurface and rust-colored horizons below, were noted in these soils (Fig. 2).

Podzols were found on the French side of the pass and are characterized by thick surface organic $(\mathrm{O})$ horizon, with light gray $(\mathrm{E})$ and rust (Bh and Bs) horizons below (Fig. 2-a, e.g., PSB3). Organic matter is also more important in the Bh horizons than in the eluvial $\mathrm{E}$ horizon. The $\mathrm{pH}$ values of these soils are also acid, in the same range of that of Stagnosols, between 3.7 and 4.8 (Fig. 2).

The amount of Fe extracted using ammonium oxalate acid and 0.1 Na-pyrophosphate solutions were $<2 \%$ in the Stagnosols and exceeded $2 \%$ in the spodic horizons of the Podzols, whereas the eluvial horizons showed very low $(<0.15 \%)$ amount of extracted $\mathrm{Fe}$. Both $\mathrm{Fe}_{\mathrm{Ox}} / \mathrm{Fe}_{\mathrm{Tot}}$ and $\mathrm{Fe}_{\mathrm{Pyr}} / \mathrm{Fe}_{\mathrm{Tot}}$ ratios in Podzols follow the same trend: iron depletion in the eluvial horizons (ratios $<0.1$ ) and enrichment in the spodic horizons ( $>0.25$ ). The $\mathrm{Fe}_{2} \mathrm{O}_{3} / \mathrm{Al}_{2} \mathrm{O}_{3}$ ratio presents the same variations, but we note that there is more $\mathrm{Al}_{2} \mathrm{O}_{3}$ than $\mathrm{Fe}_{2} \mathrm{O}_{3}$ is present in the upper part of the spodic horizon $\left(\mathrm{Fe}_{2} \mathrm{O}_{3} / \mathrm{Al}_{2} \mathrm{O}_{3}=0.8\right)$ than in it lower part $\left(\mathrm{Fe}_{2} \mathrm{O}_{3} / \mathrm{Al}_{2} \mathrm{O}_{3}=1.2\right)$. In contrast to the pattern displayed by $\mathrm{Fe}$, the $\mathrm{SiO}_{2} / \mathrm{TiO}_{2}$ ratio shows an increase in the eluvial horizon $\left(\mathrm{SiO}_{2} /\right.$ $\left.\mathrm{TiO}_{2}=50\right)$ compared to spodic horizons $\left(\mathrm{SiO}_{2} / \mathrm{TiO}_{2}=25\right)$. In the Stagnosols, the ratios do not present such pronounced variation as those seen in the Podzols. The values of $\mathrm{Fe}_{\mathrm{Ox}} / \mathrm{Fe}_{\mathrm{Tot}}$ and $\mathrm{Fe}_{\mathrm{Pyr}} / \mathrm{Fe}_{\mathrm{Tot}}$ ratios are $<0.2$, the values of $\mathrm{Fe}_{2} \mathrm{O}_{3} / \mathrm{Al}_{2} \mathrm{O}_{3}$ are largely constant and range between 0.2 and 0.4 , and the values of the $\mathrm{SiO}_{2} / \mathrm{TiO}_{2}$ ratio are higher, ranging between 40 and 60 .

Stagnosols are driven by hydrological processes and clogging of the surface (albic) horizons, especially during snowmelt, leading to the migration of Fe (II) and forming rust horizons below. Podzols are the result of the formation of organo-metallic compounds of $\mathrm{Fe}$ and $\mathrm{Al}$ in the surface horizons ( $\mathrm{O}$ and $\mathrm{E}$ ) and their migration with acidification from the eluvial horizon to the spodic Bh and Bs horizons.

Three paleosols were identified, in PSB1, PSB2 and PSB4 (Fig. 2-b). They correspond to old soils that are covered by deposits that are now developing new active soil layers. PSB1 and PSB2 display recurrences of albic and rust horizons (Fig. 2-b). The lowest rust horizons have high 
a - CURRENT PEDOGENESIS IN THE AREA OF THE PETIT SAINT BERNARD PASS

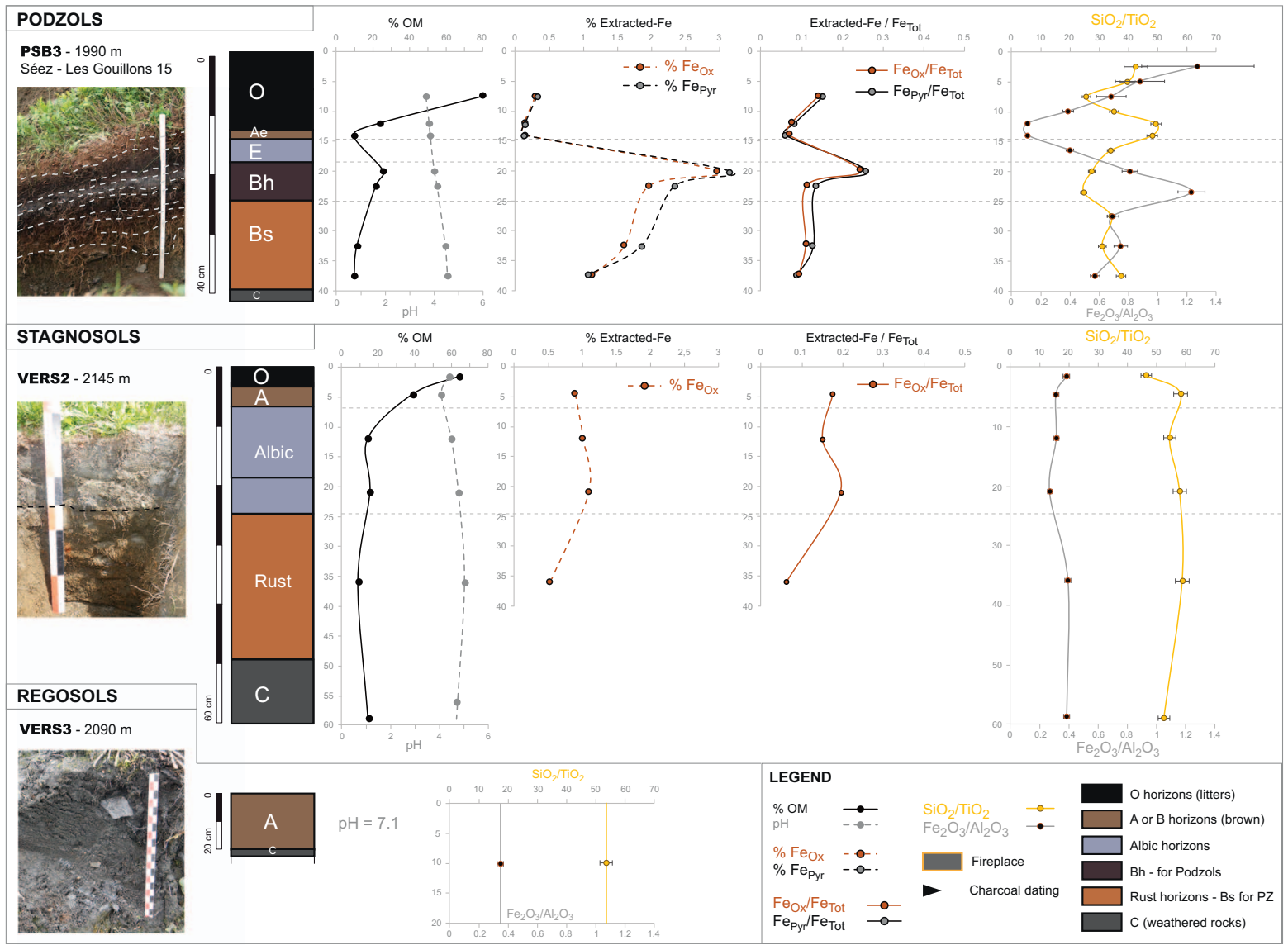

b - PALEOPEDOGENESIS IN THE AREA OF THE PETIT SAINT BERNARD PASS

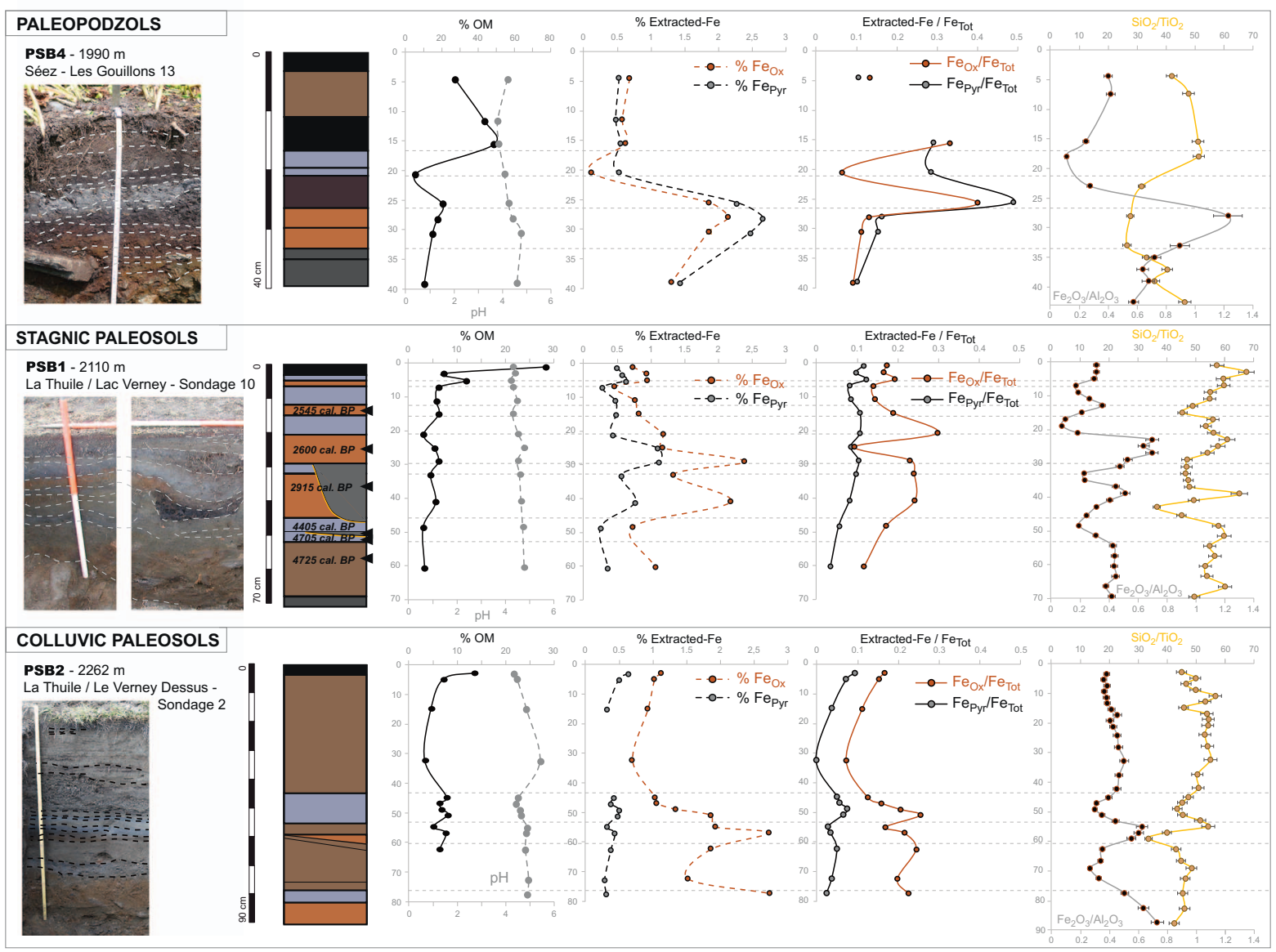




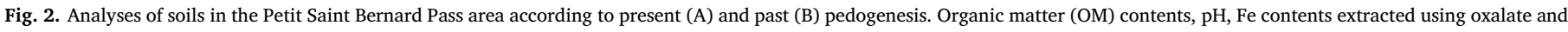

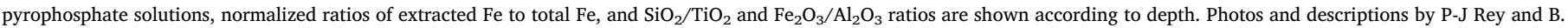
Moulin.

contents of $\mathrm{Fe}_{\mathrm{Ox}}$ and display variations in $\mathrm{Fe}_{2} \mathrm{O}_{3} / \mathrm{Al}_{2} \mathrm{O}_{3}$ and $\mathrm{SiO}_{2} / \mathrm{TiO}_{2}$ ratios, similar to those seen in the Podzols. PSB2 was covered by a succession of coarse colluvial deposits over approximately $40 \mathrm{~cm}$ in thickness. PSB1 includes two hearths at depth of 40 and $50 \mathrm{~cm}$ that have been dated using Pinus charcoals to 2915 and 4405 cal. yrs BP, respectively (Rey et al., 2014). Four other levels occurring at depths of $15,25,52$, and $58 \mathrm{~cm}$ within this profile were dated using Pinus charcoals to 2545, 2600, 4705 and 4725 cal. yrs BP. PSB4 presents an underlying succession of horizons similar to the PSB3 Podzols. Podzolic patterns were confirmed by the analysis of OM and extracted Fe. A Cambisol had developed on this paleopodzol.

\subsection{Statistical analyses of the soil horizons}

$\mathrm{Fe}_{\text {Pyr }}$, which represents the content of Fe-organic complexes, was not measured in the horizons of VERS1 and VERS2, but as $\mathrm{Si}_{\text {Ox }}$ was $<0.01 \%$ in these horizons (data not shown), we considered that the abundances of amorphous compounds were negligible. Thus, we assumed that $\mathrm{Fe}_{\mathrm{Ox}}$ would be equal to $\mathrm{Fe}_{\mathrm{Pyr}}$ in VERS1 and VERS2 and carried out the PCA using a $\mathrm{Fe}_{\mathrm{Pyr}} / \mathrm{Fe}_{2} \mathrm{O}_{3}$ ratio for all the horizons.

The correlation circle from the PCA and its corresponding biplot map for the soil samples highlighted the relations between the different elements and ratios measured in soils horizons, and allowed us to characterize each type of horizon (Fig. 3-a). Dimensions 1 and 2 (denoted as Dim 1 and Dim 2) represent $72 \%$ of the total variability. Several end members were identified on the correlation circle. The first one, which is dominated by $\mathrm{SiO}_{2}$ and the $\mathrm{K}_{2} \mathrm{O} / \mathrm{TiO}_{2}$ and $\mathrm{Al}_{2} \mathrm{O}_{3} / \mathrm{TiO}_{2}$ ratios, is positively correlated with the first dimension of the PCA and opposite to $\mathrm{Fe}_{\mathrm{Pyr}} / \mathrm{Fe}_{2} \mathrm{O}_{3}$ that is poorly and negatively correlated with this first component. A second end members is positively correlated with the second component of the PCA and yields high positive loadings for $\mathrm{TiO}_{2}, \% \mathrm{Fe}_{\mathrm{Ox}}, \mathrm{Fe}_{2} \mathrm{O}_{3}$ and $\mathrm{Fe}_{2} \mathrm{O}_{3} / \mathrm{TiO}_{2}$. It adjoins $\mathrm{Fe}_{\mathrm{Pyr}}$ and $\mathrm{Fe}_{2} \mathrm{O}_{3} /$ $\mathrm{Al}_{2} \mathrm{O}_{3}$ which are negatively correlated with $\mathrm{Dim} 1$ and positively correlated with Dim 2 . On the other hand, the $\mathrm{SiO}_{2} / \mathrm{TiO}_{2}$ ratio is positively correlated with Dim 1 and negatively correlated with Dim 2. Moreover, the organic matter and $\mathrm{CaO}$ contents are negatively correlated with both components and anticorrelated with the $\mathrm{K}_{2} \mathrm{O}$ and $\mathrm{Al}_{2} \mathrm{O}_{3}$ contents. Mapping of the horizons highlights the correlation between the surface O horizons and organic matter, and between the bleached (albic and E) horizons with $\mathrm{SiO}_{2} / \mathrm{TiO}_{2}$, but there is no possibility of distinguishing the eluvial horizons of the Podzols from the albic horizons of Stagnosols (Fig. 3-a). In contrast, this PCA allows us to distinguish spodic (Bs and $\mathrm{Bh}$ ) horizons of the Podzols, which are highly correlated with $\% \mathrm{Fe}_{\mathrm{Pyr}}$ and $\mathrm{Fe}_{2} \mathrm{O}_{3} / \mathrm{Al}_{2} \mathrm{O}_{3}$, from the rust horizons of the Stagnosols, which are positively correlated with both components of the PCA that are represented by $\mathrm{Al}_{2} \mathrm{O}_{3}$ and $\mathrm{K}_{2} \mathrm{O}$ contents. The $\mathrm{A}$ and $\mathrm{B}$ horizons, which are poorly differentiated, are located in the middle of the map and are not associated with any component. The $\mathrm{C}$ horizons are characterized by poorly weathered material and are mainly related to the second component of the PCA, which is associated with the $\mathrm{TiO}_{2}$ and $\mathrm{Fe}_{2} \mathrm{O}_{3}$ contents. We note that the surface horizons are mainly negatively correlated with the second component, and the deeper horizons are positively correlated with this component. Apart from the E horizons, the first component permitted the separation of horizons experiencing podzolization which display positively correlated OM enrichment and spodic properties, from horizons with stagnic properties, where these characteristics are negatively correlated.

\subsection{Lithology and sedimentological analyses}

Based on macro-observations of the sediment surface and on the sedimentary and geochemical analyses presented in Fig. 4, four sedimentary units were identified.

Unit 4 (2.4 to $2.12 \mathrm{~m}$ ) is composed of green-gray silts to sands and pebbles. The LOI at $550{ }^{\circ} \mathrm{C}$ presents the largest values of the sediment sequence. The grain-size distribution differs strongly from the rest of the sequence and is coarser with particles ranging in size from 40 to $200 \mu \mathrm{m}$ (Fig. 4). The XRF-intensities of Ti and the contents of $\mathrm{SiO}_{2}$ and $\mathrm{Al}_{2} \mathrm{O}_{3}$ present the lowest values of the sequence. The $\mathrm{Ca}$ intensities and $\mathrm{Fe}_{2} \mathrm{O}_{3}$ are variable whereas the $\mathrm{SiO}_{2} / \mathrm{TiO}_{2}$ ratio remains constant.

Unit 3 (2.12 to $1.7 \mathrm{~m}$ depth) is made of dark gray silt and includes some orange layer that alternate with layers containing many macrofossils and sparse fine sandy layer (Fig. 4). Unit 3 includes the largest value of LOI at $950{ }^{\circ} \mathrm{C}$ and $\mathrm{Ca}$ intensities (approximately 25\%). The grain size displays a slight fining-upward trend. All of the other geochemical parameters are highly variable, except for the $\mathrm{SiO}_{2} / \mathrm{TiO}_{2}$ ratio that seems constant but is higher than in Unit 4.

Unit 2 (1.7 to $1.15 \mathrm{~m}$ depth) is composed of gray silt with alternating fine sand and orange patterns (Fig. 4). Both the $\mathrm{Ca}$ intensities and LOI at $550{ }^{\circ} \mathrm{C}$ decrease with time. The other parameters increase with time, except for the $\mathrm{Al}_{\mathrm{Ox}} / \mathrm{Al}_{\text {Tot }}$ and $\mathrm{SiO}_{2} / \mathrm{TiO}_{2}$ ratio which remain constant; the latter ratio has higher values than the previous unit, and the $\mathrm{Fe}_{2} \mathrm{O}_{3} / \mathrm{Al}_{2} \mathrm{O}_{3}$ ratio decreases in the upper part of the unit. The grain size does not show important variations.

Unit 1, which extends from a depth of $1.15 \mathrm{~m}$ to the top, is made of dark gray to brown silts and includes fine sand layer alternating with orange patterns (Fig. 4). The $550{ }^{\circ} \mathrm{C}$ LOI is quite constant in this unit, approximately $5 \%$, and the LOI $950{ }^{\circ} \mathrm{C}$ varies slightly at the bottom of the unit and is slightly larger with an average value of $12 \%$, than in the upper part of the unit $(<10 \%)$. The NCIR increases slightly from the bottom of the unit ( $85 \%$ ) to the top (92\%). The grain size distribution in unit 1 seem to be quite homogeneous, although a higher concentration of particles with sizes of approximately $20 \mu \mathrm{m}$ occur in the upper part of the unit. The Ti intensities are higher and vary more than in the other units. The $\mathrm{Si}_{\mathrm{Ox}}$ values are very low and increase slightly in parallel with $\mathrm{SiO}_{2}$ content. Both $\mathrm{Al}_{\mathrm{Ox}}$ and the $\mathrm{Al}_{\mathrm{Ox}} / \mathrm{Al}_{\text {Tot }}$ ratio are higher in the bottom part of the unit and decrease from the bottom to the top. $\mathrm{Fe}_{\mathrm{Ox}}$ and the $\mathrm{Fe}_{\mathrm{Ox}} / \mathrm{Fe}_{\mathrm{Tot}}$ ratio increase from the bottom part of Unit 1 to a depth of $0.7 \mathrm{~m}$ and then decrease to the top. The $\mathrm{Fe}_{2} \mathrm{O}_{3} / \mathrm{Al}_{2} \mathrm{O}_{3}$ ratio displays important variations in the bottom part of unit 1 and is more nearly constant in the upper part. $\mathrm{The} \mathrm{SiO}_{2} / \mathrm{TiO}_{2}$ ratio varies rapidly and increases in the upper $0.15 \mathrm{~m}$.

\subsection{Age-depth model}

A total of 9 radiocarbon analyses were performed on selected macrofossils collected from the 2.4-m length of the sediment core (Table 1). Three radiocarbon dates were excluded from the age-depth model (bold in Table 1). Samples Poz-73372 and Poz-73373, which were dated to 8000 and $4615 \mathrm{BP}$, respectively, are clearly as too old: their macrofossils had probably been reworked, and the corresponding ages have been removed from the age-depth modeling. The third excluded sample (Poz-73374) was associated with a change in the sedimentation rate that also corresponds to the change of sedimentary units (units 2 and 1). Thus, for the age-depth model constructed using the Clam routine, this date was excluded to better reflect the change between these sedimentary units (Fig. 5-a). The model was computed with a smooth relation until SacA-32339 and interpolated below.

The measurement of short-lived radionuclides allowed the dating of the uppermost $7 \mathrm{~cm}$ of the core (Appleby and Oldfield, 1978). A logarithmic plot of ${ }^{210} \mathrm{~Pb}_{\text {ex }}$ activity (Fig. 5-b) shows a downward decrease from the surface. According to the 'constant flux, constant 

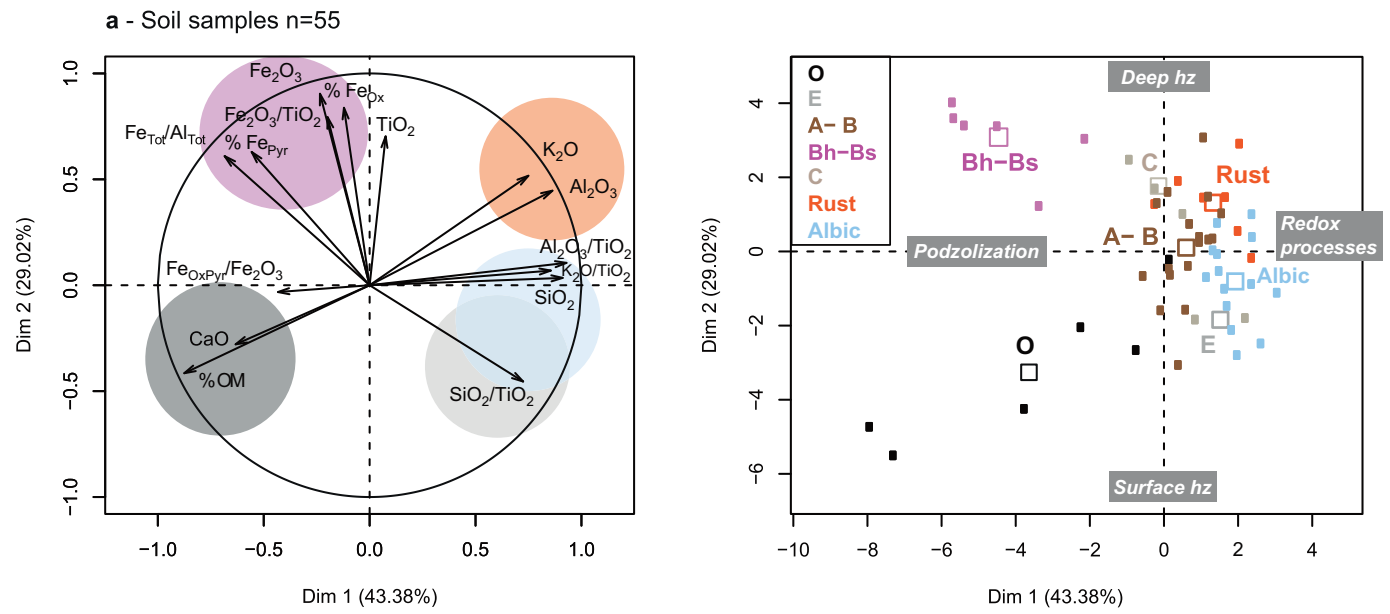

b - 1-cm thick sediment samples for selective extractions $n=32$
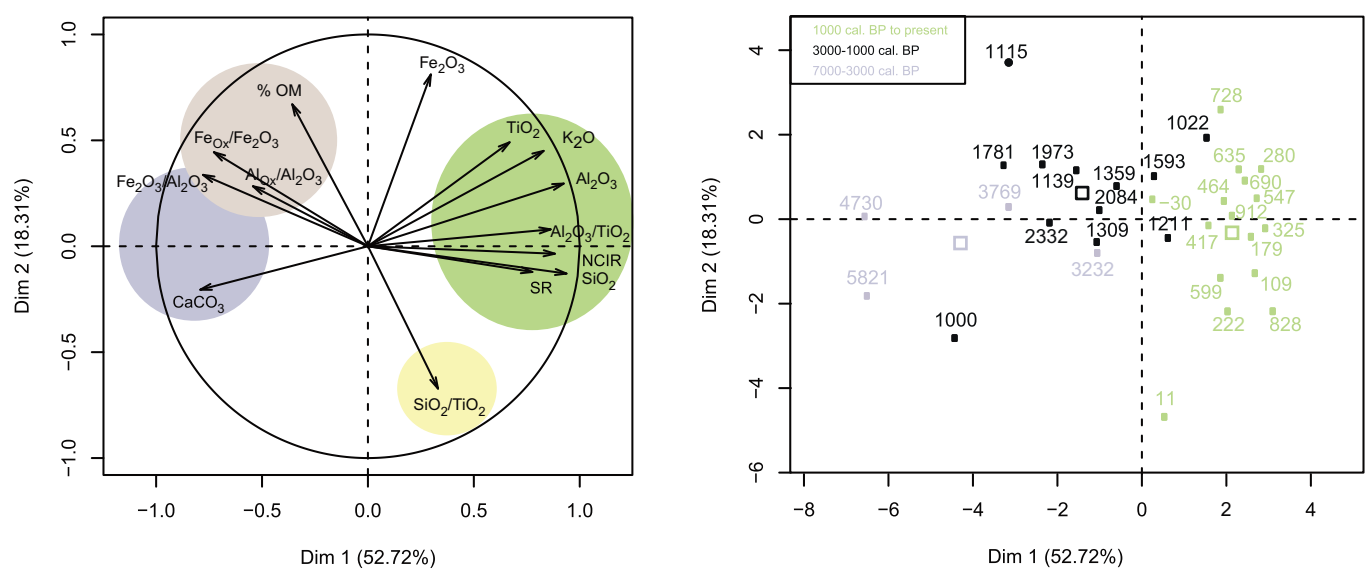

c - 3-cm thick sediment samples for DNA, pollens and NPPs analysis $n=46$
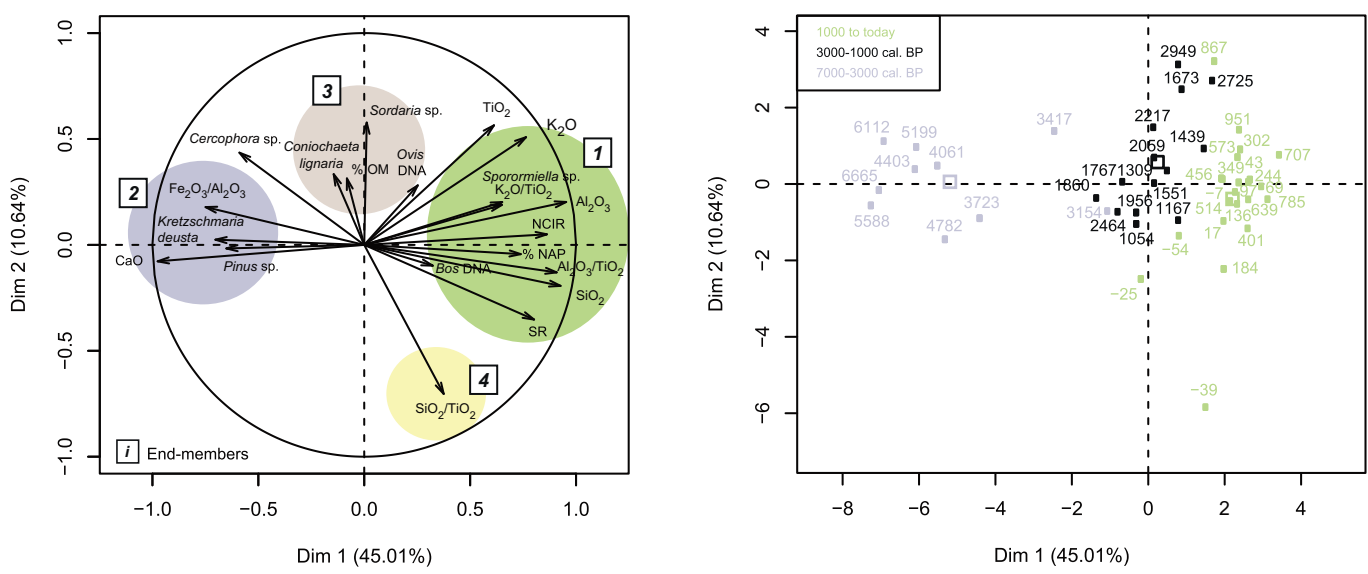

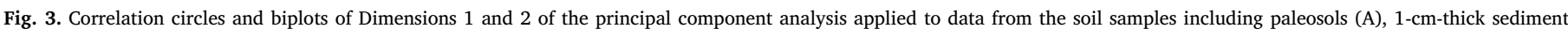

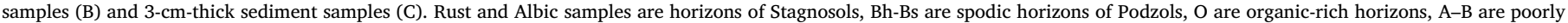

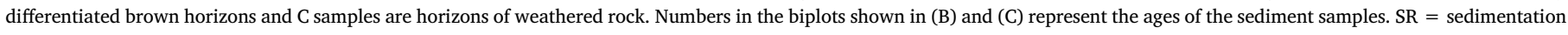
rate, $\mathrm{hz}=$ horizons.

sedimentation rate' (CFCS) model (Goldberg, 1963; Krishnaswamy et al., 1971), the levels of ${ }^{210} \mathrm{~Pb}_{\text {ex }}$ indicate a mean accumulation rate of $0.7 \mathrm{~mm} \cdot \mathrm{yr}^{-1}$. The ${ }^{137} \mathrm{Cs}$ activity profile (Fig. 5-b) has a peak at a depth of $4.05 \pm 0.25 \mathrm{~cm}$ and reaches a maximum at $2.05 \pm 0.25 \mathrm{~cm}$, interpreted respectively as the beginning of atmospheric production of ${ }^{137} \mathrm{Cs}$, in 1955 (due to nuclear tests) and the Chernobyl accident in 1986 (Robbins and Edgington, 1975). The expected high ${ }^{137} \mathrm{Cs}$ activity associated with the maximum intensity of nuclear weapons testing in the
Northern Hemisphere in AD 1963 may lie between these two depths; however, it is not clearly identifiable likely due to both the low resolution of the analyses and the large amount of fallout from Chernobyl. The good agreement between the ages of the artificial radionuclide peaks inferred from the 210Pbex-CFCS model (1956 and 1984) and the actual ages of artificial radionuclide peaks (1955 and 1986) suggests that these dates provide an accurate and continuous age-depth relationship within the upper $7 \mathrm{~cm}$ of the sediment sequence. These data 


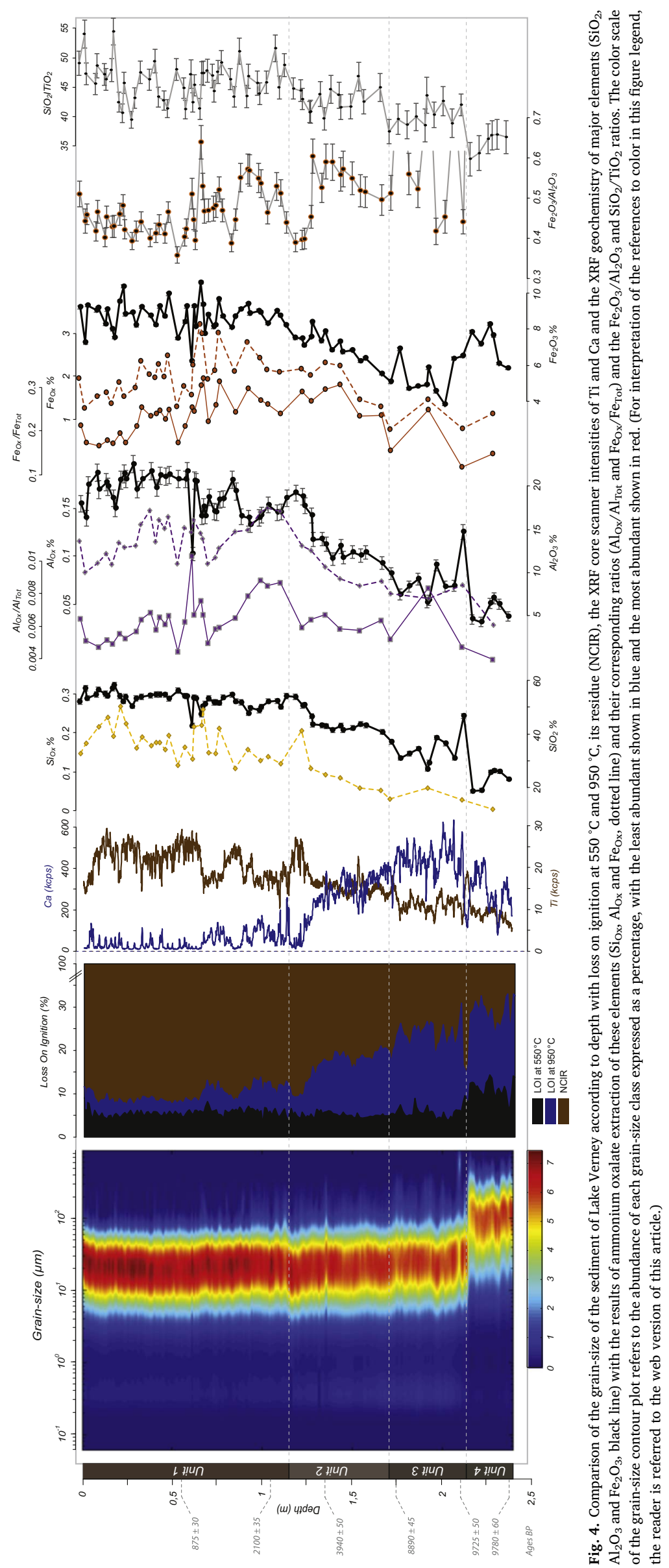




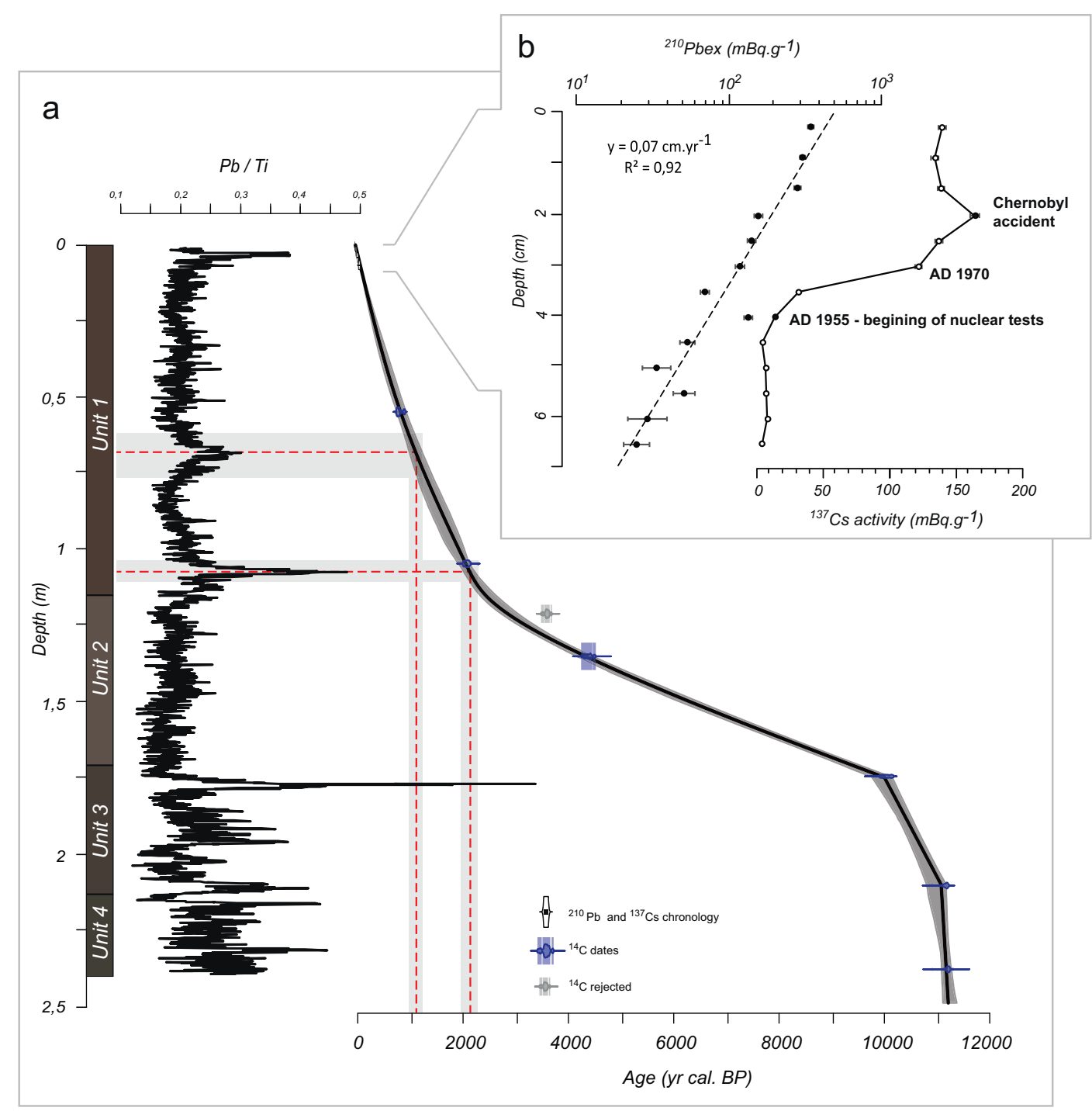

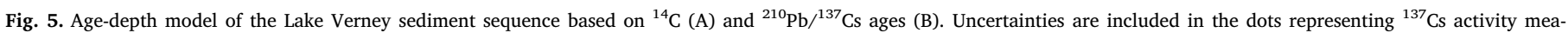
surements. The $\mathrm{Pb} / \mathrm{Ti}$ ratios enable comparison of the model with the $\mathrm{Pb}$ emissions during modern, Medieval and Roman periods.

were incorporated into Clam to generate the age-depth model of the whole core alongside the ${ }^{14} \mathrm{C}$ age estimates (Fig. 5-a).

The age-depth model shows three major phases with differing sedimentation rates within the $2.4 \mathrm{~m}$ of the sediment sequence (Fig. 5-a). Units 4 and 3 span the period from 11,200 to 9200 cal. yrs BP and have a mean sedimentation rate of $0.7 \mathrm{~mm} \cdot \mathrm{yr}^{-1}$ (Fig. 6-a). Unit 2 covers the period between 9200 and 2400 cal. yrs BP and has a mean sedimentation rate of $0.07 \mathrm{~mm} \cdot \mathrm{yr}^{-1}$. The sedimentation rate of unit 1 increases from 0.2 to $0.7 \mathrm{~mm} \cdot \mathrm{yr}^{-1}$ over the last $2400 \mathrm{cal}$. yrs BP up to the present (Fig. 6-a).

The variations in the values of the $\mathrm{Pb} / \mathrm{Ti}$ ratio measured using the $\mathrm{XRF}$ core scanner show four periods of increases in $\mathrm{Pb}$ intensity (Fig. 5a). At the bottom of the core, before 10,000 cal. $\mathrm{yrs} \mathrm{BP}, \mathrm{Pb}$ is considered to be linked to the organic matter within the sediment. After 10,000 cal. yrs BP, the three other increases are consistent with the Roman period, the Medieval period and modern emissions of leaded gasoline, respectively, and these peaks support our age-depth model (Arnaud et al., 2004; Elbaz-Poulichet et al., 2011).

\subsection{Quantification of non-arboreal pollen (NAP) and NPPS}

On average, NAP represents $16 \%$ of the total pollen from 11,400 to 3000 cal. yrs BP (Fig. 6-h). It increases from 3000 to 2000 cal. yrs BP to a maximum of $42 \%$. NAP is once again at an average of $16 \%$ from 2000 to $1100 \mathrm{cal}$. yrs BP and increases again (up to 50\%) after $1100 \mathrm{cal}$. yrs BP.

Among NPPs, we focus only on fungal ascospores produced in the catchment that grow on plant remains, within the soil litter, and in fecal material. Cercophora sp. (HdV-112), Coniochaeta ligniaria (HdV-172) and Kretzschmaria deusta (HdV-44) are assumed to be saprophytic fungal ascospores associated with the degradation of the litter associated with deciduous trees (Doyen and Etienne, 2017;), whereas Sordaria sp. (HdV-55B), Sporormiella sp. (HdV-113) and Podospora sp. (HdV-368) are saprophytic/coprophilous or strictly coprophilous fungal ascospores (Etienne and Jouffroy-Bapicot, 2014; Doyen and Etienne, 2017; Etienne et al., 2013). NPP types were summed relative to their saprophytic or fecal ecological indicator value and expressed in abundances (no $\mathrm{cm}^{-3}$ ) and accumulation rates (no $\mathrm{cm}^{-2} \cdot \mathrm{yr}^{-1}$ ) (Fig. 6-f-g).

The abundances of saprophytic spores increase from $11,400 \mathrm{cal}$. yrs BP to a maximum at approximately 9000 cal. yrs BP. They decrease progressively until $3200 \mathrm{cal}$. yrs BP. On the other hand, accumulation rates remain low during the early and mid-Holocene, except between 3500 and 3900 cal. yrs BP (Fig. 6-f). The accumulation rates of saprophytic NPPs and their abundances follow the same trend during the last 3000 years, with four major increases occurring from 2600 to 2000 cal. yrs BP, 1600 to 1300 cal. yrs BP, 900 to 700 cal. yrs BP and 


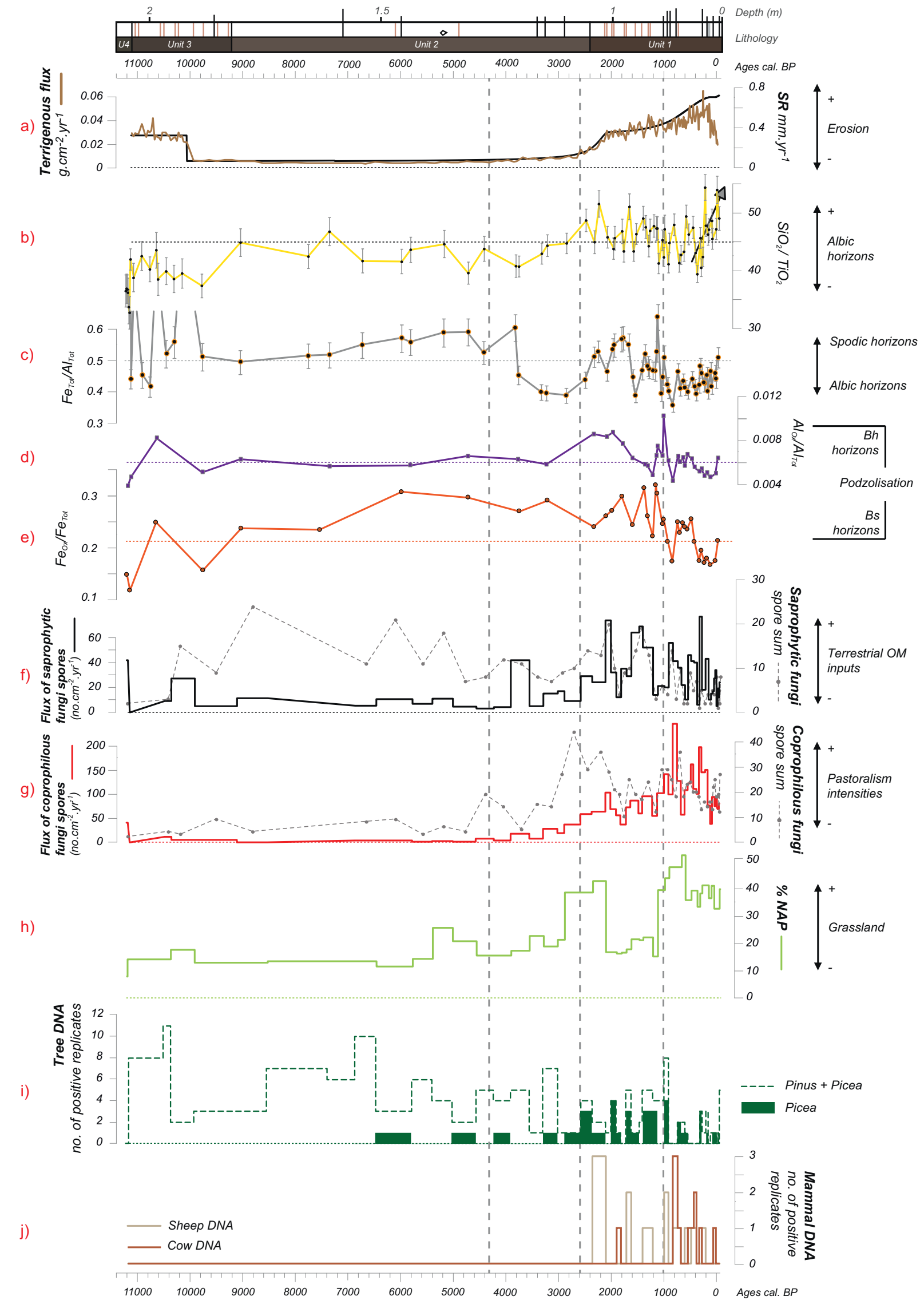

(caption on next page) 


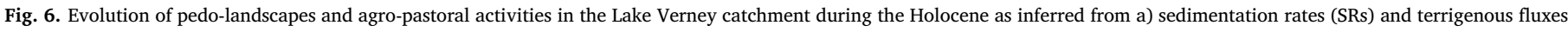

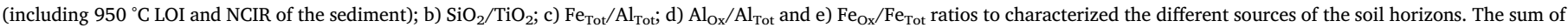

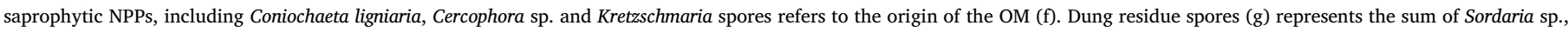

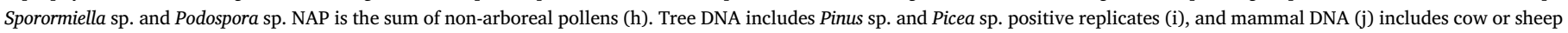
DNA positive replicates.

500 to 300 cal. yrs BP.

The abundances and accumulation rates of coprophilous ascospores both remain low until 4400 cal. yrs BP $(<10$ spores and $<20$ spore $\cdot \mathrm{cm}^{-2} \cdot \mathrm{yr}^{-1}$, respectively (Fig. 6-g)). The abundances of these spores reach 20 spores between 4400 and 4000 cal. yrs BP and a maximum value between 3000 and 2000 cal. yrs BP (45 spores). They remain high during the last 2000 years (10 to 35 spores), with small decreases occurring between 1800 and 1200 cal. yrs BP and 300 and $100 \mathrm{cal}$. BP. The accumulation rates increase progressively from 4000 to $800 \mathrm{cal}$. yrs BP, up to 250 spore $\mathrm{cm}^{-2} \cdot \mathrm{yr}^{-1}$, and remain high (100 to 200 spore $\cdot \mathrm{cm}^{-2} \cdot \mathrm{yr}^{-1}$ ), with short-term decreases occurring at approximately 700 cal. yrs BP and during the last 150 years (Fig. 6-g).

\subsection{Sedimentary DNA}

The DNA of five mammalian taxa was found in the sediments of Lake Verney, specifically Bos sp. (cattle), Equus sp. (horse), Felis sp. (cat), Ovis sp. (sheep) and Sus sp. (pig). Equus, Felis and Sus were only detected in one or two samples within the sequence. Because these animals are uncommon in alpine pasture contexts, we focus only on DNA of Bos sp. and Ovis sp. (Fig. 6-j). No DNA from either Ovis or Bos was detected in sediments older than 2360 cal. yrs BP. DNA of Ovis sp. was found in 10 samples from 2360 to 200 cal. yrs BP. In samples with ages ranging from 2360 to 900 cal. yrs BP, sheep DNA was generally detected in multiple replicate PCR analyses per sample, whereas it was only detected in one out of 12 PCR replicates after 900 cal. yrs BP. DNA of Bos sp. was only detected in one PCR replicate between 2360 and 900 cal. yrs BP. After 900 cal. yrs BP, Bos DNA was found in 8 samples, in 1 to 3 positive PCR replicates per samples.

There are currently no trees in the catchment of Lake Verney. Among the DNA of trees found in the sediments, Pinus is a pioneer species in the Alps whereas Picea became established in the region at $c a$. 3000 yrs BP (David, 1993; de Beaulieu et al., 1993). Pinus DNA was found in at least one replicate in all samples with ages between 11,200 and $2900 \mathrm{cal}$. yrs BP, with an average of 5 positive replicates per sample (Fig. 6-i). During the second part of the Holocene, the number of positive replicates decreased. It was then found in between 0 and 2 replicates since 2900 cal. yrs BP, except between 1000 and 900 cal. yrs BP and in the most recent sample (4 positive replicates). Picea DNA appears punctually at ca. 6000, 5000 and 4000 cal. yrs BP with just one positive replicate (Fig. 6-i). After 3000 cal. yrs BP, it was detected more often, with up to 4 positive replicates per sample, especially between 2600 and 1000 cal. yrs BP.

\subsection{Statistical endmembers}

In order to avoid the influence of the bottom of the sediment sequence, which shows substantial variations in composition and sedimentation rates, PCA analyses were only performed on sediments with ages of 7000 years or less.

The first two components of the PCA performed using the data set of sediment selective extractions $(n=32)$ represent $71 \%$ of the variability (Fig. 3-b). The arrangement of variables according to both dimensions is similar to the PCA results from the soil samples. However, OM is more closely related to variations in iron, and it is positively correlated with the first component and negatively correlated with the second one, and the $\mathrm{Fe}_{2} \mathrm{O}_{3}$ and $\mathrm{TiO}_{2}$ contents appear to be drawn toward the axis of the first component and its terrigenous endmembers. The sedimentation rate (SR) and NCIR are also related to this group, supported by the first component. $\mathrm{SiO}_{2} / \mathrm{TiO}_{2}$ is always positively correlated with the first component and negatively with the second one, while the calcium carbonate content is negatively correlated with both components. Finally, the values of the $\mathrm{Al}_{\mathrm{Ox}} / \mathrm{Al}_{\text {Tot }}$ ratio in the sediment seem to follow the same changes in the iron ratios and the OM contents.

The first two dimensions of the PCA performed using the data set including NAP, Pinus DNA and spore abundances of Kretzschmaria deusta, Cercophora-type, Coniochaeta ligniaria, Sordaria sp. and Sporormiella sp. represent $56 \%$ of the total variability (Fig. 3-c), and the resultst of this PCA appear to reproduce the same scheme as the PCA of the data set including selective extraction of $\mathrm{Fe}$ and $\mathrm{Al}$ (Fig. 3-b). Four endmembers can be identified. NAP, which is positively correlated with the first component, is strongly linked to the elements of terrigenous origin and ratios involving those elements. In contrast, $\mathrm{CaO}$ content, Pinus DNA, the spores of Kretzschmaria deusta, $\mathrm{Fe}_{2} \mathrm{O}_{3}$ and $\mathrm{Al}_{2} \mathrm{O}_{3}$ form a second group and are negatively correlated with the first group. A third endmembers that is associated with OM content and Sordaria and Coniochaeta ligniaria spores show a weak positive correlation with the second component of the PCA. Spores of the Cercophora-type are located between these two last endmembers and are positively correlated with the first component and negatively with the second one. As Ovis and Bos DNA occur sporadically in the sediment, their representativeness is poor in the PCA. Ovis DNA seems to be associated with both OM and terrigenous inputs. On the other hand, Bos DNA is especially closely related to the terrigenous endmembers and the sedimentation rate and by the $\mathrm{SiO}_{2} / \mathrm{TiO}_{2}$ ratio. These components make up the fourth endmember, which is positively correlated with the first component and negatively correlated with the second one. The spores of Sporormiella sp. are situated between the directions of Ovis and Bos DNA, which is consistent with their relationship to pastoralism (Etienne and JouffroyBapicot, 2014; Doyen and Etienne, 2017).

The biplot mapping of the results of both sediment PCAs according to the ages of the sediment samples shows a gradation along the first component, from the oldest sediments (7000-3000 cal. yrs BP), which are negatively correlated with the first axis, to the more recent sediment (1000 cal. yrs BP to the present), which are positively correlated with the first axis (Fig. 3-b-c). The sediments of the period between 3000 and 1000 cal. yrs BP are situated in the middle of the first axis and seem to be more closely associated with the second component.

\section{Discussion}

\subsection{Sediment origins}

Sediment inputs in the lake represent both changes in the pedolandscape around Lake Verney and the diversity of that pedo-landscape, just as the current soils do, and areas of preferential erosion. These sediments continuously record a mix of different sources, depths and degrees of weathering, including, in a global way, the expected dominant processes. They also record the main eroded areas that are the steepest slopes, mainly upstream, surrounding the lake and areas where erosion is induced by human activities. The steep slopes concern only Regosols or Leptosols that are expected to provide always the same constant contribution through time, downstream and to the sediment record. The study of erosion before the development of human activities, i.e., on long time-scale, allows us to dissociate this erosion source from the expected human induced erosion, assuming that other more advanced soil types are few eroded in the absence of human activity. Our goal is to differentiate the main sources of material, referring to the main pedogenetic processes that have occurred in the catchment. Both carbonate schist in the west and black shales in the east can provide 
calcium (through dissolution) and calcium carbonates (through physical erosion) in the lake. Calcium carbonates recorded in the sediment may come from both terrigenous and authigenic inputs, but both inputs can reflect early conditions of soil development (decarbonatation), with small inputs of weathered material or the loss of carbonate material from young soils at the beginning of pedogenesis and associated with the rejuvenation of soils, e.g. on steep slopes (Bajard et al., 2017). The OM contents recorded in the sediments are constant over the last 10,000 yrs, whereas the sediment flux has increased. This result suggests that the $\mathrm{OM}$ was derived from the catchment and was not produced authigenically in the lake. The terrestrial origin of the OM is supported by the record of saprophytic fungi spores, which show comparable abundances before and after the increase in erosion (Fig. 6f).

\subsection{Record of soil footprints in the sediments}

Identification of the soils that fed the lake sediments is made possible by the characterization of current soils on both hillsides of the pass and by the high differentiation of horizons between the soil types identified and within the same soil. Both the soils of the lake catchment and the soils close to the lake catchment were compared to the sediment record in order to catch all pedogenetic processes that could no longer operate in the lake catchment. Soils and especially paleosols were also considered to validate our interpretation from the sediment sequence. The development of undifferentiated and thin Regosols on limestone, whereas the other soils are acid, suggests that the decarbonatation from rock to soil during weathering is relatively fast. Only the coarse fragments in the matrix effervesce to $\mathrm{HCl}$ solution, and these elements can provide terrigenous carbonates to the lake. This quick acidification also allowed the development of Podzols on material that had previously been leached of carbonate (e.g., PSB3 and PSB4) over relative short timescales (e.g., Bormann et al., 1995).

Both Podzols and Stagnosols are very acid soils ( $\mathrm{pH} 4$ to 5, e.g., PSB3 and VERS2); thus, they can develop from acid Cambisols. Both are characterized by different horizons, albic and rust in particular.

\subsubsection{Identified albic horizons}

The albic horizons of both the Podzols and Stagnosols are characterized by a light color ("bleached" or "whitened") and are enriched in silica (high ratios of $\mathrm{SiO}_{2} / \mathrm{TiO}_{2}$ ), reflecting the eluvial character of these horizons (Figs. 3-a and 7). In consequence, they are difficult to distinguish, except for the E horizons of Podzols. These horizons occur between OM-rich horizons; thus, they are more often associated with organic matter than albic horizons, which are conversely more closely associated with strictly terrigenous materials, such as $\mathrm{SiO}_{2}, \mathrm{~K}_{2} \mathrm{O}$ and $\mathrm{Al}_{2} \mathrm{O}_{3}$ (Figs. 3-a and 7).

\subsubsection{Differentiation of the rust horizons of Stagnosols from the spodic horizons of Podzols}

The rust horizons of Stagnosols and the spodic horizons of Podzols are well differentiated by different variables with regard to the PCA performed on the soil samples (Fig. 3-a). The spodic horizons are characterized by high values of $\mathrm{Fe}_{\mathrm{Ox}}, \mathrm{Fe}_{\mathrm{Pyr}}$, and $\mathrm{Fe}_{\mathrm{Tot}} / \mathrm{Al}_{\mathrm{Tot}}$, whereas the rust horizons of Stagnosols are more strongly characterized by $\mathrm{K}_{2} \mathrm{O}$ and $\mathrm{Al}_{2} \mathrm{O}_{3}$. Organo-metallic complexes of $\mathrm{Al}$ and $\mathrm{Fe}$ form in the sub-surface horizons of Podzols and accumulate in the Bh and Bs horizons (Fig. 7). Al-OM complexes can accumulate to a greater degree in Bh horizons under hydromorphic conditions (Anderson et al., 1982; Legros, 2007). Based on the studies of Mourier et al. (2008, 2010), these geochemical proxies are the characteristics that we will look for in the sediment, assuming their conservative behavior during mobilization, transport and deposition from the catchment to the lake and that they did not form in the lake (Fig. 7). This assumption is possible considering the small size of the lake catchment, and the smaller areas in the catchment concerned by soils and not only scree. Climatic and $\mathrm{pH}$ conditions are also in favor of low biological and chemical changes of soil-sediment properties within the lake (i.e., low temperatures and higher $\mathrm{pH}$ in soils than in the lake).

Only extractions with ammonium oxalate solution were performed on sediment samples. $\mathrm{Fe}_{\mathrm{Ox}}, \mathrm{Al}_{\mathrm{Ox}}$, and $\mathrm{Si}_{\mathrm{Ox}}$ represent the amount of both amorphous and complexed forms, whereas extractions with Na-pyrophosphate only extract the complexed forms. The Podzols are characterized by the presence of OM-complexes and the small differences between $\mathrm{Fe}_{\mathrm{Pyr}}$ and $\mathrm{Fe}_{\mathrm{Ox}}$ seen in PSB3 and PSB4. These results indicate that little or no amorphous material was present in the Podzols. The very low contents of $\mathrm{Si}_{\mathrm{Ox}}$ in the sediment indicate that there are no amorphous compounds of $\mathrm{Si}$, and thus we assumed that there are also no amorphous compounds of $\mathrm{Fe}$ and $\mathrm{Al}$, as we did for the horizons of VERS1 and VERS2. Furthermore, the microbial activity of the lake could change Fe-OM complexes into amorphous compounds (Birkeland, 1999; Mourier et al., 2010). In consequence, the contents of $\mathrm{Fe}_{\mathrm{Ox}}$ and $\mathrm{Al}_{\mathrm{Ox}}$ are attributed to the OM-complexes of spodic horizons. Finally, as the sediment reflects a mixture of different sources, we normalized $\mathrm{Fe}_{\mathrm{Ox}}$ and $\mathrm{Al}_{\mathrm{Ox}}$ to the contents of total iron $\left(\% \mathrm{Fe}_{2} \mathrm{O}_{3}\right)$ and aluminum $(\%$ $\mathrm{Al}_{2} \mathrm{O}_{3}$ ), respectively, to trace the inputs from spodic horizons into the lake (Fig. 7). In the PCA performed using data from the selective extractions of sediments (Fig. 3-b), both the $\mathrm{Fe}_{\mathrm{Ox}} / \mathrm{Fe}_{\text {Tot }}$ and $\mathrm{Al}_{\mathrm{Ox}} / \mathrm{Al}_{\text {Tot }}$ ratios are strongly correlated with the $\mathrm{Fe}_{\mathrm{Tot}} / \mathrm{Al}_{\text {Tot }}$ that strongly characterizes the spodic horizons, thus supporting our interpretation.

\subsection{Evolution of soils and agro-pastoral activities throughout the Holocene, as inferred and dated from sediment archives of Lake Verney}

\subsubsection{1,000 to $4300 \mathrm{cal}$. BP: from decarbonatation of the catchment to acidification of soils}

The composition and chronology of unit 4, which was deposited between 11,200 and 11,100 \pm 100 cal. yrs BP suggests instantaneous deposition of this unit, similar in its carbonated nature to the parent material, at the beginning of the lake sedimentation (Figs. 1, 4 and 5-a). The sedimentation dated to 11,100 and 10,000 cal. yrs BP is rapid but lower than the sedimentation rates seen in unit 4 and displays a high variability in the $\mathrm{OM}$ contents and the values of the $\mathrm{Fe}_{2} \mathrm{O}_{3} / \mathrm{Al}_{2} \mathrm{O}_{3}$ ratio.

Between 10,000 and 4300 cal. yrs BP, erosion was lower, and Pinus DNA became abundant (Fig. 6-i). The high abundance of charcoals of Pinus cembra found in four soil profiles in the area of the pass confirms that the DNA recorded in Lake Verney come from this species (Talon, 2006). Five of them were found at $1940 \mathrm{~m}$ on the French side of the pass and were dated to between 4325 and 3910 cal. yrs BP (Talon, 2006), in agreement with the chronology of Pinus DNA in the sediment (Fig. 6-i). The abundance of saprophytic spores between 10,000 and 4300 cal. yrs BP, confirms the development of litter horizons under the forest (Fig. 6-f). At the same time, the carbonate contents decrease and the values of $\mathrm{Fe}_{\mathrm{Ox}} / \mathrm{Fe}_{\mathrm{Tot}}$ ratio increase, suggesting that organic acids from the forest litter contributed to the dissolution of the soil carbonates and acidified the soils, permitting dissolution of Fe, which formed complexes with OM compounds and migrated through the soils, and could be laterally transported into the lake. The change in carbonate contents in the early to mid-Holocene sediment appear to have been controlled mainly by weathering of the catchment, favored by forest covers (Giguet-Covex et al., 2011; Dreibrodt and Wiethold, 2015; Bajard et al., 2017). The values of $\mathrm{Al}_{\mathrm{Ox}} / \mathrm{Al}_{\mathrm{Tot}}$ ratio do not vary within the sediment deposited during this period, perhaps due to the lower mobility and lower contents of $\mathrm{Al}_{\mathrm{Ox}}$ compared to $\mathrm{Fe}_{\mathrm{Ox}}$. In consequence, it is possible that the $\mathrm{Al}$ complexes migrated within the soils, as did the Fe complexes, forming spodic horizons but not reaching the lake. The development of spodic horizons is corroborated by the increase in the values of the $\mathrm{Fe}_{\mathrm{Tot}} / \mathrm{Al}_{\mathrm{Tot}}$ ratio in the lake sediment between 10,000 and $4300 \mathrm{cal}$. yrs BP. Moreover, the time between the beginning of pedogenesis and $4300 \mathrm{cal}$. yrs BP seems long enough to allow the differentiation of such horizons (Bormann et al., 1995; Protz et al., 1984). Pedogenesis may have been favored by the climate warming that 


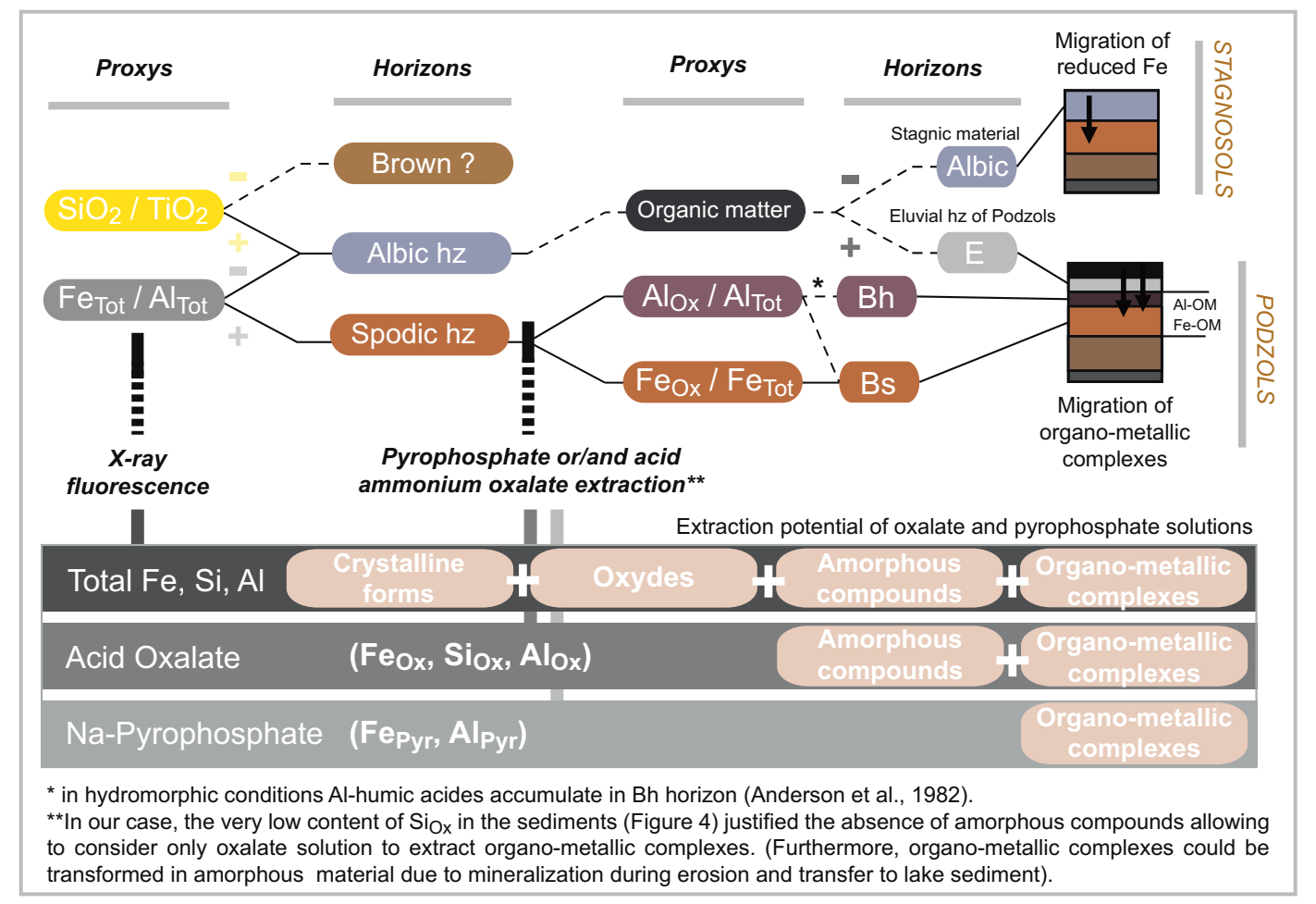

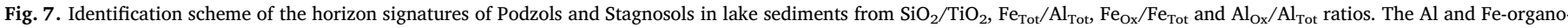
metallic complexes that characterize the spodic horizons of Podzols were extracted with the acid ammonium oxalate solution. Hz $=$ horizon, Ox $=$ oxalate, Pyr $=$ pyrophosphate.

occurred during this period, which is assumed to have reach its maximum between 6000 and 7000 cal. BP (Millet et al., 2008). Thus, following the loss of carbonate compounds, acidification led to the development of Podzols in the catchment of Lake Verney, where no Podzols are currently present. Neither DNA nor NPPs indicate human activities in the Lake Verney catchment before 4300 cal. yrs BP.

4.3.2. 4300 to 2600 cal. BP: first human occupation in the catchment: deforestation and litter erosion

From 4300 cal. yrs BP, erosion increased gradually from 0.004 to $0.008 \mathrm{~g} \cdot \mathrm{cm}^{-2} \cdot \mathrm{yr}^{-1}$ and forest reduction and inputs of coprophilous fungi spores represent the first opening of the landscape to human activities in the catchment (Fig. 6-a-h-i). Fire episodes inferred from the anthracological study of Talon (2006) are consistent with forest clearing at this altitude and during this period. The migration of Picea into the area of the pass may have been favored by human activities (Miras et al., 2006).

The variability in Kretzschmaria deusta and Coniochaeta ligniaria was related to the Pinus DNA and the OM contents, respectively (Fig. 3-c) and suggest an erosion of litter and soil organic horizons between 4000 and 3600 cal. yrs BP (Fig. 6-f). Erosion of surface soil horizons could explain the substantial amount of Pinus DNA detected when clearing was initiated. On the other hand, the absence of mammal DNA in the sediment could reflect a low intensity of pastoral activities.

After 3800 cal. yrs BP, the input of albic material increased (Fig. 6b). Following the erosion of the organic horizons, erosion of the eluvial horizons of the Podzols seems to be the most convincing hypothesis for this increase, but we cannot exclude erosion of the albic horizons of the Stagnosols. Indeed, the albic and rust horizons of the Stagnosols are more closely associated with $\mathrm{TiO}_{2}, \mathrm{Al}_{2} \mathrm{O}_{3}$ and $\mathrm{SiO}_{2}$ than the $\mathrm{E}$ horizons of the Podzols (Fig. 3-a), suggesting that the first record of stagnic horizons occurred between 2900 and 2600 cal. yrs BP (Figs. 4 and 6).

\subsubsection{0 to $1000 \mathrm{cal}$. BP: erosion of spodic horizons}

During the Second Iron Age and the Roman period, pastoral activity steadily increased, as reflected by the occurrence of substantial amounts of NAP, whereas the detection of tree DNA diminishes (Fig. 6g-h-i). According to the mammal DNA, more sheep flocks than herds of cows were going up to pasture around the pass during this period (Fig. 6-j). In association with this intensification of pastoral activities, the erosion rate strongly increased between 2600 and 1900 cal. yrs BP, as both of the $\mathrm{Al}_{\mathrm{Ox}} / \mathrm{Al}_{\mathrm{Tot}}$ and $\mathrm{Fe}_{\mathrm{Tot}} / \mathrm{Al}_{\text {Tot }}$ ratios, followed by the increase in $\mathrm{Fe}_{\mathrm{Ox}} / \mathrm{Fe}_{\mathrm{Tot}}$ after $1900 \mathrm{cal}$. yrs BP, indicating the successive erosion of the Bh and Bs spodic horizons of the Podzols (Fig. 6-a-c-d-e). This result indicates that the erosion of the albic horizons during the previous period was more closely associated with eluvial horizons than the albic horizons of Stagnosols. The variability in the values of $\mathrm{SiO}_{2} / \mathrm{TiO}_{2}$ and $\mathrm{Fe}_{\mathrm{Ox}} / \mathrm{Fe}_{\mathrm{Tot}}$ ratios between 1900 and 1000 cal. yrs BP seems to indicate mixing with material from albic horizons, especially between 1600 and 1400 cal. yrs BP when lower values of the $\mathrm{Fe}_{\text {Tot }} / \mathrm{Al}_{\text {Tot }}$ ratio are noted. Except for $\mathrm{SiO}_{2} / \mathrm{TiO}_{2}$, the values of all the ratios (i.e., $\mathrm{Al}_{\mathrm{Ox}} / \mathrm{Al}_{\mathrm{Tot}}, \mathrm{Fe}_{\mathrm{Ox}} /$ $\mathrm{Fe}_{\mathrm{Tot}}$ and $\mathrm{Fe}_{\mathrm{Tot}} / \mathrm{Al}_{\mathrm{Tot}}$ ) began to decline around 1900 cal. yrs BP, suggesting a change in pedogenetic processes, from podzolization to the development of stagnic properties. Erosion of the Bh and Bs horizons is supported by the occurrence of the two periods during which the largest terrigenous fluxes took place and by the terrestrial OM inputs (Fig. 6-af), which could reflect the organic character of the eroded horizons, and could have been transported with the $\mathrm{Al}$ and $\mathrm{Fe}-\mathrm{OM}$ complexes (Wilmshurst and McGlone, 2005).

Between the Antiquity and the Middle Ages, during the so-called "Dark Ages", a significant decrease in the NAP associated with an increase in the tree DNA was recorded, indicating recolonization of the site by pine (likely Pinus cembra) and spruce (Fig. 6-h-i). In a few short centuries, this recolonization could have led to a recovery in podzolic processes as suggested by the slight increases in the spodic ratios (i.e., $\mathrm{A}_{\mathrm{lOx}} / \mathrm{Al}_{\text {Tot }}, \mathrm{Fe}_{\mathrm{Ox}} / \mathrm{Fe}_{\mathrm{Tot}}$ and $\mathrm{Fe}_{\mathrm{Tot}} / \mathrm{Al}_{\text {Tot }}$ ). This recovery of the forest is supported by both human and climate forcing. Hearths found around the Roman building were dated to between 1834 and $1580 \mathrm{cal}$. yrs BP (Rey et al., 2015). These dates are in accordance with the old coin inventory of Rémy et al. (2006), and suggest at least use of the pass at that 
time. The destruction of the Roman building at approximately 1600 cal. yrs BP and the occurrence of a colder period recorded approximately $1700 \mathrm{cal}$. yrs BP (Millet et al., 2008) could be related to abandonment of the area and the beginning of this new, short-live pedogenetic phase.

\subsection{4. $1000 \mathrm{cal}$. BP to present: development of stagnic properties}

From 1000 to $100 \mathrm{cal}$. yrs BP, erosion rates continued to increase, from 0.04 to $0.06 \mathrm{~g} \cdot \mathrm{cm}^{-2} \cdot \mathrm{yr}^{-1}$. Between 1000 and $400 \mathrm{cal}$. yrs BP, mammal DNA, NAP and the spores of coprophilous fungi spores reach their maxima (Fig. 6-h-i-j). They increase again between 400 cal. yrs BP and the present. During both of these periods, the occurrence of tree DNA remains sporadic, indicating that clearing was maximum, as it does today, without trees in the catchment. The most important change in pastoral activities is reflected by the most pronounced detection of Bos DNA that suggests an increase in cattle breeding after the MiddleAges. Indications of podzolization become more and more sparse, and the development of stagnic properties has dominated pedogenesis since at least $400 \mathrm{cal}$. yrs BP.

\subsection{Validation of soil evolution with current soils, paleosol and anthracological analyses}

The current soils, the studied paleosols, plus the anthrocological study performed by Talon (2006), in the area of the Petit Saint-Bernard Pass as part of the Alpis Graia Interreg Project, provide elements that support the soil evolution scenario proposed using the sediment record from Lake Verney.

First, the current pedogenesis of the lake catchment, dominated by stagnic properties, is consistent with the interpretation of the latest sediment deposits. No evidence of Podzols was found in the lake sediment for the last 400 years cal. BP, in agreement with the current absence of Podzols in the catchment of Lake Verney. Podzols can develop at higher altitudes than those found on the French side of the pass (e.g., PSB3) and on the black shales of the Houillere Briançonnais area and below the subalpine Rhododendron heaths, as reported by Mourier et al. (2008). The development of true Podzols is also possible on calcareous schists (obviously after decarbonatation), and in wet climates, such as those found in the Northern Alps (Legros and Martini, 1992). Podzols developed on Liassic calcareous schists have been described from the Balme Pass $(2200 \mathrm{~m})$, located $40 \mathrm{~km}$ to the north of the Petit Saint-Bernard Pass (Dambrine, 1985). Thus, the current absence of Podzols around Lake Verney cannot result from the altitude of the lake, which is above $2088 \mathrm{~m}$, nor from the geological materials underlying the catchment.

Clear evidence of spodic horizons were identified in the sediment record, especially between the mid-Holocene period and the Middle Ages. Paleopodzols like those seen in PSB4 have been found at lower altitudes $(2000 \mathrm{~m})$ on the French side of the pass, indicating that old, but undated Podzols had developed and were subsequently covered by erosion induced deposits. Erosion increased beginning $4300 \mathrm{cal}$. yrs BP; thus, it is possible that Podzols were present before $4300 \mathrm{cal}$. yrs BP. Moreover, the deepest charcoals found within a Podzol (beyond the organic-mineral horizon) at $1940 \mathrm{~m}$ of elevation were dated to 1210 and 4160 cal. yrs BP (Talon, 2006). The other 8 dates obtained from this profile ranged from 2105 to 4325 cal. yrs BP, except for one sample that yielded an age of $330 \mathrm{cal}$. yrs BP and was obtained from the organic surface horizons. These charcoals indicate that fire episodes occurred during this interval, and that Podzols were present in the area of the pass before the Roman period and before the strong increase in erosion.

Among the successive albic and rust horizons of both paleosols PSB1 and PSB2, the deepest rust horizons display high contents of $\mathrm{Fe}_{\mathrm{Ox}}$, and slightly more $\mathrm{Fe}_{\mathrm{Pyr}}$ was noted in PSB1 (at depth of approximately 30 and $40 \mathrm{~cm}$ ). These characteristics are reminiscent of the spodic character of the Podzols, even if the values are 2 to 3 times less important than for Podzols (Fig. 2). The other albic and rust patterns do not display these characteristics. Our hypothesis is that these deep, $\mathrm{Fe}_{\mathrm{Ox}}$-enriched horizons represent old degraded spodic horizons. Removal of the surface horizons and their exposure could allow the mineralization and degradation of organo-metallic complexes and the formation of amorphous compounds, e.g., ferrihydrite, suggested by the high ammonium oxalate extractable Fe fraction (Birkeland, 1999; Stucki et al., 1988). OM-complexed forms can oxidize due to drainage and form ferrihydrite. This process is characteristic of acid hydromorphic soils (Jeanroy, 1983). Hydromorphic processes may have been present in the Podzols but had only a weak effect while podzolization occurred.

Furthermore, if we consider the thicknesses of the Podzols currently found in the area of the Petit Saint-Bernard Pass, to the Bs horizons, i.e., approximately $30 \mathrm{~cm}$ (PSB3, Fig. 2-a), and the period during which the Podzols were eroded, approximately 3000 yrs (between 4000 and $1000 \mathrm{cal}$. BP), the potential erosion rate is $0.1 \mathrm{~mm} \cdot \mathrm{yr}^{-1}$ on average. This order of magnitude falls within the range of erosion rates triggered by agricultural management over the last two millennia (Enters et al., 2008; Massa et al., 2012; Bajard et al., 2017). It is also in the commonly admitted range of soil formation rates (Montgomery, 2007; Larsen et al., 2014) and raises the question of the sustainability of the pasture, which appears to be in equilibrium with the activities taking place in the catchment.

Charcoals were only found in PSB1 and were dated. Six ${ }^{14} \mathrm{C}$ dates provide information on the different levels and hearths found within the soil (Fig. 2). The deepest horizons were dated to 4725 and 4705 cal. yrs BP. Just below, the deepest hearth was dated to 4405 cal. yrs BP. The second larger hearth was dated to 2915 cal. yrs BP. The two other rust levels above were dated to 2600 and 2545 ca1. yrs BP. Both hearths were considered to represent sporadically occupied campsites. Nevertheless, they allowed determination of the ages of the rust and albic patterns at the same burial levels. The evidence of spodic horizons is thus older than 2600 cal. yrs BP. In the sediments, erosion of the spodic Bh horizons, followed by the Bs horizons was recorded after $2600 \mathrm{cal}$. yrs $\mathrm{BP}$, which is consistent with the absence of these horizons in the soils after $2600 \mathrm{cal}$. BP. Dates obtained from potential old spodic levels in PSB1 that range from approximately 3000 and 2600 cal. yrs BP are also consistent with dates obtained from a Podzol by Talon (2006) at an elevation of $1940 \mathrm{~m}$. Moreover, two other profiles at $2000 \mathrm{~m}$ on the Italian side of the pass (La Thuile/Plan Veyle Verney 3-2000 $\mathrm{m}$ and La Thuile/Plan Veyle Verney 2-2004 m) also contain hearths and albic levels that are contemporary with the recorded human activities (Rey et al., 2014). Thus, the stagnic horizons seem to be more recent than the spodic horizons, suggesting that hydromorphic processes began to dominate the Podzolization. A Roman tile found in the albic horizon of a current Stagnosol (Col du Petit Saint-Bernard Sondage 14) confirms this trend (Rey and Moulin, 2006).

\subsection{Pedo-landscape evolution around the Petit Saint-Bernard Pass and implication for the evolution of the ecosystem cycle}

Following glacier retreat and lake formation, Cambisols are expected to have quickly developed and acidified in the area of the pass, helped by the growth of vegetation, particularly by Pinus cembra (Fig. 8a-b-c). On the steeper slopes, colluvial movement of soils may have regularly rejuvenated these Cambisols, as seen in VERS3 (Figs. 2 and 8e). Furthermore, within the upper part of the catchment, pedogenesis was likely slower, due to the sparser vegetation, longer periods of snow cover, steeper slopes and rock landslides that are found there. Thus, only weakly differentiated profiles are found in the western part of the catchment of Lake Verney, as reported by Talon (2006). As a consequence, Regosols and Cambisols were present in the landscape throughout the Holocene, though they may have been more strongly represented in the landscape before podzolization (Fig. 8-a-b-c).

The process of Podzolization seems to have progressed after 10,000 cal. yrs BP and likely reached its maximum between 6000 and 


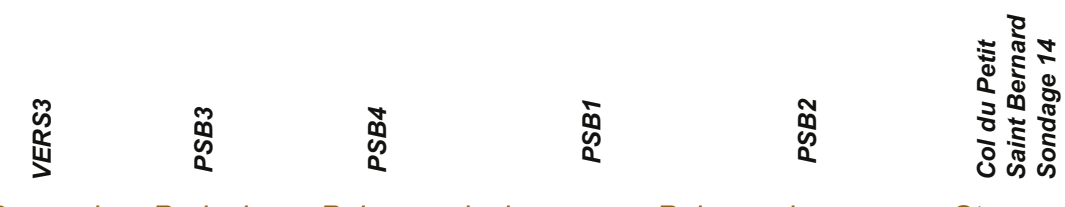

Regosols Podzols Palaeopodzols

Palaeosols

Stagnosols

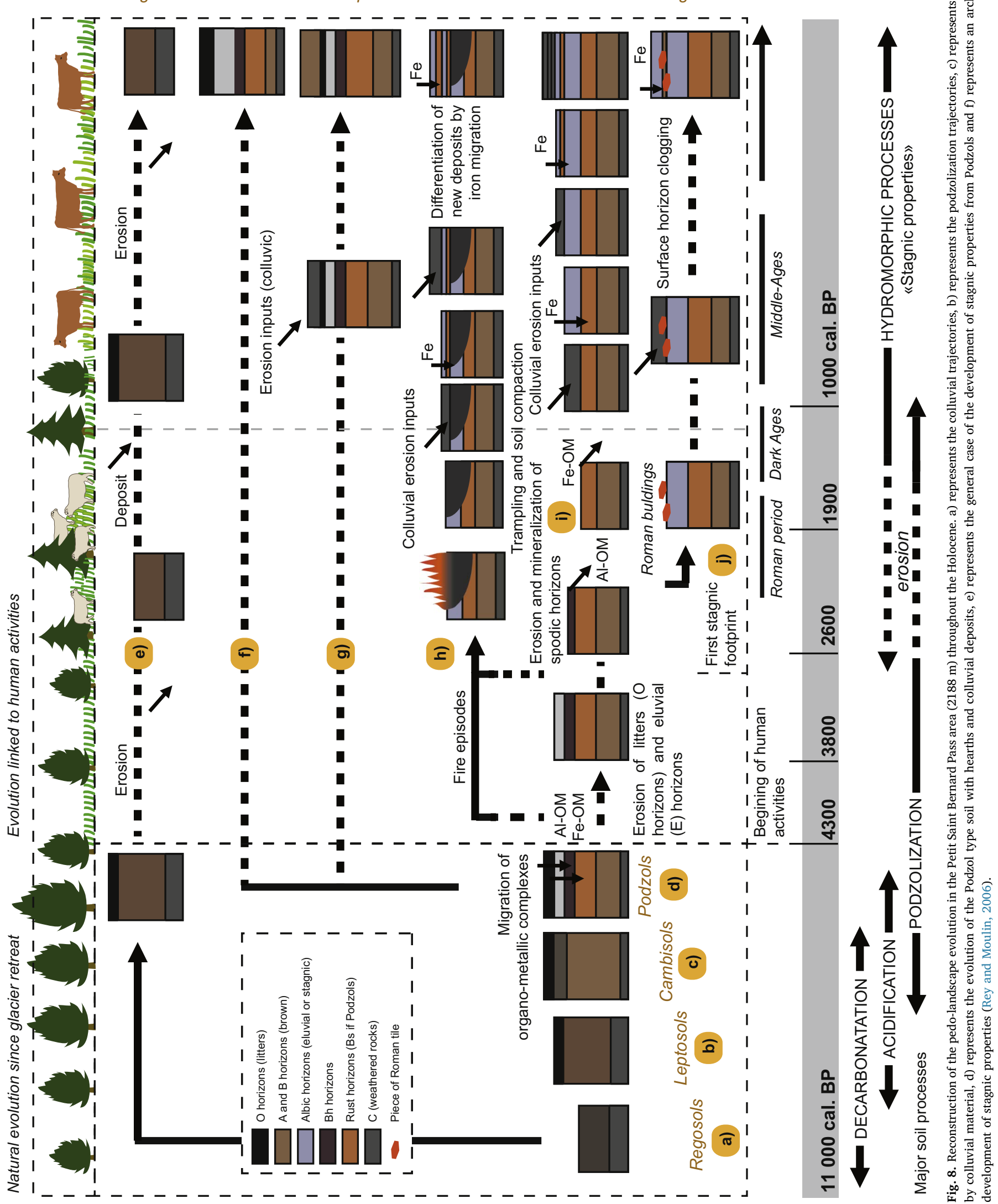


4000 cal. yrs BP (Figs. 6 and 8-d). Following the beginning of human activities at approximately 4300 cal. yrs BP, changes in vegetation cover that were associated with an increase in erosion disrupted the soils that were present in the area of the pass. First, between 4300 and 2600 cal. yrs BP, soil litter and organic surface horizons were eroded, followed by the eluvial horizons of Podzols and parts of the spodic horizons between 2600 and 1000 cal. yrs BP (Fig. 8-h-i). A current analog was described by Pallmann (1947), who reported that, following thinning of a Pinus cembra forest, the settlement of grass and pasture led to a rapid degradation of acid humus horizons, transforming Podzols into poorly developed Podzols, grazing triggering a regression in soil evolution, and mixing the previously well-defined horizons.

As erosion increased, the spodic horizons came to the surface and mineralized, forming amorphous compounds. These compounds could be mobilized and transported or they could be covered with new materials (spodic or other) from upper parts of the slope (Fig. 8-h-i-j). In some cases, as PSB4, erosion deposited material that buried the former soils, consequently forming paleosols (Figs. 2 and 8-g) In the upper part of PSB2, regular inputs of coarse elements, slightly weathered, associated with higher $\mathrm{pH}$ of 8 would have led to the prevention of $\mathrm{Fe}$ migration and the differentiation of rust and albic horizons (Figs. 2 and 8 -i). Regular deposits are much easier to mobilize than the fine material generated from calcareous schists which is prone to solifluction, generating humps and hollows (Legros and Martini, 1992).

Archaeological evidence, such as the hearths noted in PSB1 (Fig. 8h) or the piece of Roman tile found in Séez/Col du Petit Saint-BernardSondage 14 (Fig. 8-j) are sometimes found between two levels of deposits. A new deposit is then emplaced producing new material for pedogenesis that dissociates between rust and albic levels due to the presence of vegetation. Indeed, change in litter, and new hydrological conditions in the soils of the catchment can prevent podzolization. Modification of hydrological conditions associated with pedogenetic change occurred due to the change in vegetation from native forest to land clearing (Willis et al., 1997; Mourier et al., 2010) but also due to the long use of the pasture over millennia and the possible development of irrigation in the area of the pass (Rey, 2011). Indeed, hydrological changes such as drainage can led to rapid changes in soil properties (Montagne et al., 2016). Several authors have described the degradation of Podzols, but mainly in term of evolution into Cambisols (Dambrine, 1985; Willis et al., 1997; Mourier et al., 2008; Poulenard et al., 2015). For example, Dambrine (1985) described the degradation of Podzols into Cambisols I in response of the spread of agriculture into altitude pasturelands. The climate-specific conditions of the Petit SaintBernard Pass and the possible initially hydromorphic properties of the Podzols could have prevented from their development into Cambisols.

In the Middle Ages, the changes in the composition of herds, from primarily sheep to cows and/or the intensification of pastoralism appear to have been responsible for both the intensification of erosion and the acceleration of hydromorphic processes. Cattle can compact soils and cause increased runoff (Trimble and Mendel, 1995), changing the susceptibility of soils to water erosion (Giguet-Covex et al., 2011; Brisset et al., 2017). However, the depletion of soils in organic matter, due to the degradation of Podzols and the development of Stagnosols can also be responsible for degradation of the soil structure (Oldeman, 1994), and this process can accentuate erosion without any change in pasture intensity as a possible feedback process (Yaalon and Yaron, 1966).

To established a general model of soil evolution trajectories, we replace the soil evolution of the Petit Saint Bernard pass area in the ecosystem cycle evolution described by Holling (1986) and adapted for soil cycle functioning by Poulenard et al. (2015) (Fig. 9). The cycle is made up of 2 axes that correspond to Capital versus Connectedness and organization which were adapted to Stock and Fluxes for the soil system (Poulenard et al., 2015). We choose to address organic carbon here because it appears relevant for the evolution of soils in the Petit SaintBernard Pass area, because it can help distinguish e.g., Podzols from
Stagnosols, as well as the different horizons of Podzols, and because it is a key constituent that is necessary for soil ecosystem services. Both axes are controlled by the soil-forming factors (Jenny, 1941), of which we emphasize the Human effect as a major soil-forming factor (Yaalon and Yaron, 1966; Richter, 2007). However, its presence as an individual factor is questionable because of its ability to change all the others. The third axis which accounts for parent material (p) and relief (r), represents the spatial dimension and the diversity of the pedo-landscape. The cycle begins with a phase of rapid soil growth (R), following glacial retreat and the formation of Leptosols and Cambisols, as described in the early Holocene soil evolution (Figs. 8 and 9). The soils reach a relative steady state, which is defined as the conservation phase (K). The organic carbon is maximal, and this phase corresponds to the Holocene climatic optimum and the maximal expansion of both Podzols $\left(\mathrm{S}_{1}\right)$ and Pinus cembra forest in the subalpine area (Figs. 8-d and 9). The $\Omega$ phase is initiated in our case by the beginning of human activities and represents a phase of release, characterized by deforestation, erosion and the haploidization of soil horizons. The haploidization process was introduced to describe the mixing and/or loss of soil horizons (Fig. 9) and contrasts with horizonation (Hole, 1961; Johnson and Watson-Stegner, 1987). Carbon stock decreases according to the horizons, and fluxes vary according to the intensity of the exported stock. Each single soil within the landscape follows a particular $\Omega$ trend that depends on local and temporal pressures, such as use as a campsite, overgrazing and according to the topography (the third dimension), which allows export and/or deposition of eroded material, thus multiplying the pedogenesis trajectories and increasing pedodiversity (Ibañez et al., 1995). The $\Omega$ phase is an intense, short and regressive phase that brings soils to a less developed state than they had during the $\mathrm{K}$ phase; and in some case to complete erosion of soils $\left(\mathrm{S}_{0}\right)$. The $\alpha$ phase constitutes a reorganization phase that is characterized by a rebalancing of the soil cover due to the existence of new environmental (i.e., hydrology, vegetation, grazing...) conditions, leading to the development of Stagnosols $\left(\mathrm{S}_{2}\right)$ and to the beginning of a new cycle (Fig. 9). Contrary to (Holling, 1986), the $\alpha$ phase cannot be assimilated into a new $\mathrm{R}$ phase because soils do not return to their initial condition and develop from the degraded, previously existing soil. Yaalon and Yaron (1966) introduced the term of metapedogenesis $\left(\mathrm{m}_{\mathrm{i}}\right)$ to indicate "the $[\mathrm{hu}] \mathrm{man}$-induced processes and changes in the soil profile". The pristine soil evolution defines the pedogenesis, and the different $\Omega$ - $\alpha$ trajectories of the ecosystem define the anthropo-pedogenetic phases. Thus, the soil $S_{i+1}$ (with $i \neq 0$ ) results from the anthropo-pedogenesis $m_{i}$ applied to $S_{i}$ and so on: $\mathrm{S}_{\mathrm{i}+1}=\mathrm{f}\left(\mathrm{S}_{\mathrm{i}}, \mathrm{m}_{\mathrm{i}}\right)$. The $\Omega-\alpha$ trajectories are directly involved in the provision of ecosystem services from the soil's natural capital (Dominati et al., 2010), and permit quantification and valuation of the ecosystem services provided by pasture soils (Dominati et al., 2014).

\section{Conclusion}

The study of the Holocene sediment sequence of Lake Verney and the analysis of current pedogenesis in the area of the Petit Saint-Bernard Pass allowed us to reconstruct the evolution of past soil processes in relation to past human activities. According to the substantial content of carbonate material in the sediment, decarbonatation seems to have been the main process that occurred during the first part of the Holocene. The acidification of the soils due to the presence of Pinus cembra vegetation and the increase in the $\mathrm{Fe}_{\mathrm{Ox}} / \mathrm{Fe}_{\mathrm{Tot}}$ ratio until 6000 cal. yrs BP indicate the formation and migration of Fe organometallic compounds allowed the podzolization of the soils within the catchment during the mid-Holocene period. The beginning of human activities was recorded at $4300 \mathrm{cal}$. yrs BP, and was associated with land clearing and the successive erosion of the surface of Podzols horizons. During the Roman period, the spodic horizons were stripped away, meanwhile, erosion increased in response to sheep grazing. During the Middle Ages, pasturing way to cattle farming. Erosion increased again while the $\mathrm{Fe}_{\mathrm{Ox}} / \mathrm{Fe}_{\mathrm{Tot}}$ ratio decreased, suggesting that the 


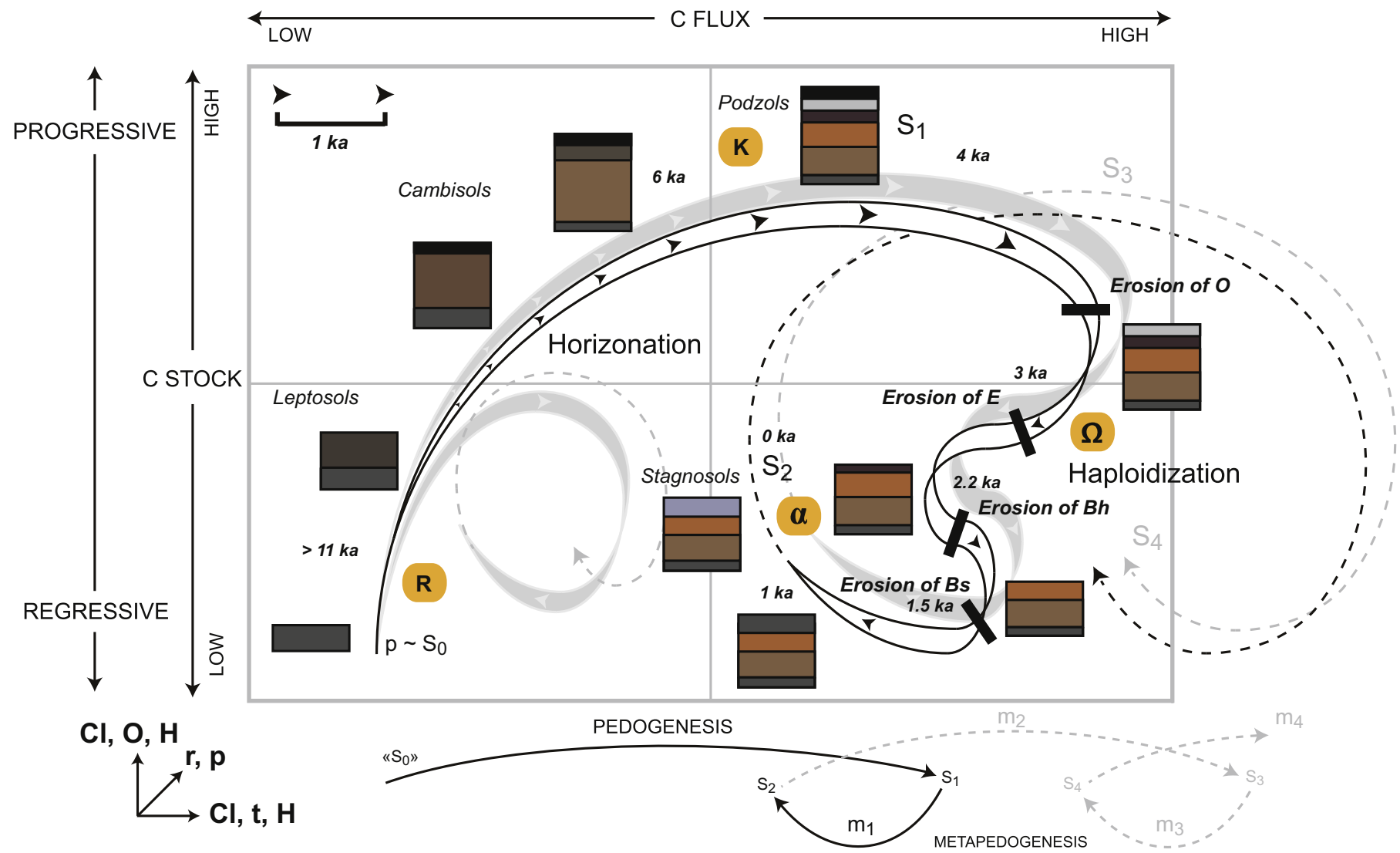

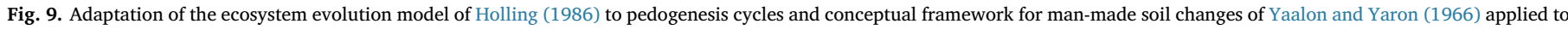

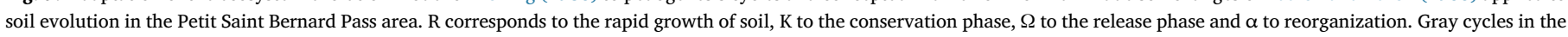

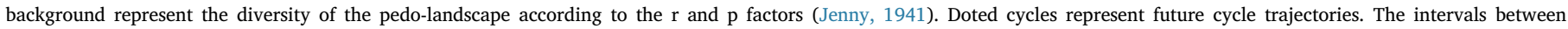

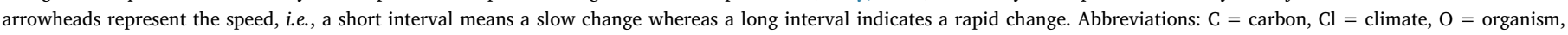
$\mathrm{H}=$ human, $\mathrm{r}=$ relief, $\mathrm{p}=$ parent material, $\mathrm{t}=$ time, $\mathrm{Si}=$ soil $\mathrm{i}, \mathrm{mi}=$ metapedogenetic phase $\mathrm{i}$.

Podzols evolved into Stagnosols since that time. The study of paleosols, archaeological evidence and charcoal dating from soils in the area of the pass allowed validation of the soil evolution reconstruction from the lake sediment archive. The paleosols also confirmed the development of Stagnosols from degraded spodic horizons and provide additional information on erosional processes and the chronology of the Anthropocene. The combined studies of lake sediment archives and paleosols provide a long-term continuous reconstruction of pedogenesis at the landscape scale. Our study highlights the effect of the human soilforming factor in the soil cycle evolution, and provides evidence of "anthropo-pedogenetic" phases. More than changes in vegetation and agro-pastoral activities, it is more the continuous use and progressive degradation of the soil cover that lead to soil changes. The change in soil type from Podzols to Stagnosols leads to reduced accumulation of organic matter that may have consequences for both the soil structure, favoring erosion, and carbon sequestration. This understanding of "release-reorganization" trajectories, i.e., the anthropo-pedogenesis, could provide a possible means to quantify and value long-term soil ecosystem services.

\section{Acknowledgments}

The authors thank the city of La Thuile in Italy (Roberto Maddalena and Barbara Frigo) for access and coring authorizations and the ski resort of La Rosière for the winter access to the lake by the ski slopes. Thanks to Stéphanie Thiebault and Claire Delhon for charcoals identification of PSB1, Julie Deyrieux for the sedimentological analyses, Aurélien Borgeat, Manu Mallet and Pierre Faivre for field support. Thanks also to Sarah Bureau for ICP-AES analyses at ISTerre laboratory and to Delphine Rioux from LECA laboratory for DNA sampling and analyses. 14C analyses were acquired thanks to the CNRS-INSU ARTEMIS national radiocarbon AMS measurement program at Laboratoire de Mesure du 14C (LMC14) in the CEA Institute at Saclay (French Atomic Energy Commission). The authors thank also the Laboratoire Souterrain de Modane (LSM) facilities for the gamma spectrometry measurements. This research was performed by Hannibal Project financed by the DIPEE (Dispositifs de Partenariat en Ecologie et Environnement) Chambéry-Grenoble of the CNRS INEE.

\section{References}

Adhikari, K., Hartemink, A.E., 2016. Linking soils to ecosystem services - a global review. Geoderma 262, 101-111. http://dx.doi.org/10.1016/j.geoderma.2015.08.009. Anderson, H.A., Berrow, M.L., Farmer, V.C., Hepburn, A., Russell, J.D., Walker, A.D., 1982. A reassessment of podzol formation processes. Eur. J. Soil Sci. 33, 125-136.

Appleby, P., Oldfield, F., 1978. The calculation of lead-210 dates assuming a constant rate of supply of unsupported $210 \mathrm{~Pb}$ to the sediment. Catena $5,1-8$.

Appleby, P., Richardson, N., Nolan, P., 1991. 241Am dating of lake sediments. In: Environmental History and Palaeolimnology. Springer, pp. 35-42.

Arnaud, F., Revel-Rolland, M., Bosch, D., Winiarski, T., Desmet, M., Tribovillard, N., Givelet, N., 2004. A 300 year history of lead contamination in northern French Alps reconstructed from distant lake sediment records. J. Environ. Monit. 6, 448-456. http://dx.doi.org/10.1039/B314947A.

Arnaud, F., Révillon, S., Debret, M., Revel, M., Chapron, E., Jacob, J., Giguet-Covex, C., Poulenard, J., Magny, M., 2012. Lake Bourget regional erosion patterns reconstruction reveals Holocene NW European Alps soil evolution and paleohydrology. Quat. Sci. Rev. 51, 81-92. http://dx.doi.org/10.1016/j.quascirev.2012.07.025.

Arnaud, F., Poulenard, J., Giguet-Covex, C., Wilhelm, B., Révillon, S., Jenny, J.-P., Revel, M., Enters, D., Bajard, M., Fouinat, L., et al., 2016. Erosion under climate and human pressures: an alpine lake sediment perspective. Quat. Sci. Rev. 152, 1-18.

Baize, D., 2000. Guide des analyses en pédologie: 2e édition, revue et augmentée. (Editions Quae).

Bajard, M., Sabatier, P., David, F., Develle, A.-L., Reyss, J.-L., Fanget, B., Malet, E., 
Arnaud, D., Augustin, L., Crouzet, C., Poulenard, J., Arnaud, F., 2016. Erosion record in Lake La Thuile sediments (Prealps, France): evidence of montane landscape dynamics throughout the Holocene. The Holocene 26, 350-364.

Bajard, M., Poulenard, J., Sabatier, P., Develle, A.-L., Giguet-Covex, C., Jacob, J., Crouzet, C., David, F., Pignol, C., Arnaud, F., 2017. Progressive and regressive soil evolution phases in the Anthropocene. Catena 150, 39-52. http://dx.doi.org/10.1016/j.catena. 2016.11.001.

Birkeland, P.W., 1999. Soils and Geomorphology, 3rd ed. Oxford University Press, New York.

Blaauw, M., 2010. Methods and code for "classical" age-modelling of radiocarbon sequences. Quat. Geochronol. 5, 512-518. http://dx.doi.org/10.1016/j.quageo.2010. 01.002 .

Bormann, B.T., Spaltenstein, H., McClellan, M.H., Ugolini, F.C., Cromack Jr., K., Nay, S.M., 1995. Rapid soil development after windthrow disturbance in pristine forests. J. Ecol. 747-757.

Boyer, F., Mercier, C., Bonin, A., Le Bras, Y., Taberlet, P., Coissac, E., 2016. Obitools: a unix-inspired software package for DNA metabarcoding. Mol. Ecol. Resour. 16, $176-182$.

Brisset, E., Miramont, C., Guiter, F., Anthony, E.J., Tachikawa, K., Poulenard, J., Arnaud, F., Delhon, C., Meunier, J.-D., Bard, E., Sumera, F., 2013. Non-reversible geosystem destabilisation at 4200 cal. BP: sedimentological, geochemical and botanical markers of soil erosion recorded in a Mediterranean alpine lake. The Holocene 23, 1863-1874. http://dx.doi.org/10.1177/0959683613508158.

Brisset, E., Guiter, F., Miramont, C., Troussier, T., Sabatier, P., Poher, Y., Cartier, R., Arnaud, F., Malet, E., Anthony, E.J., 2017. The overlooked human influence in historic and prehistoric floods in the European Alps. Geology G38498-1.

COM EU, 2006. Communication from the Commission to the Council, the European Parliament, the European Economic and Social Committee and the Committee of the Regions - Thematic Strategy for Soil Protection [SEC(2006)620] [SEC(2006)1165]/* COM/2006/0231 Final $*$.

Crogiez-Petrequin, S., 2006. Col du Petit Saint Bernard: Les fouilles du bâtiment ouest 2003-2005 Epoque Gallo-Romaine, in: Actes Du Séminaire de Clôture Du Programme INTERREG III A ALCOTRA 2000-2006: Alpis Graia. Archéologie sans Frontière Au Col Du Petit St-Bernard. Aoste. pp. 131-141.

Daily, G.C., Matson, P.A., Vitousek, P.M., 1997. Ecosystem services supplied by soil. In: Nature's Services: Societal Dependence on Natural Ecosystems, pp. 113-132.

Dambrine, É., 1985. Contribution à l'étude de la répartition et du fonctionnement des sols de haute montagne: massifs des Aiguilles Rouges et du Mont-Blanc.

David, F., 1993. Évolutions de la limite supérieure des arbres dans les Alpes françaises du Nord depuis la fin des temps glaciaires.

de Beaulieu, J., Kostenzer, J., Reich, K., 1993. Dynamique forestière holocène dans la haute vallée de l'Arve (Haute-Savoie) et migrations de Abies et Picea dans les Alpes occidentales. Dissertationes Botanicae. 196. pp. 387-398.

Dearing, J., Hu, Y., Doody, P., James, P.A., Brauer, A., 2001. Preliminary reconstruction of sediment-source linkages for the past $6000 \mathrm{yr}$ at the Petit Lac d'Annecy, France, based on mineral magnetic data. J. Paleolimnol. 25, 245-258.

Development Core Team, R., 2011. R: A Language and Environment for Statistical Computing. R Foundation for Statistical Computing, Vienna, Austria.

Dominati, E., Patterson, M., Mackay, A., 2010. A framework for classifying and quantifying the natural capital and ecosystem services of soils. Ecol. Econ. 69, 1858-1868. http://dx.doi.org/10.1016/j.ecolecon.2010.05.002.

Dominati, E., Mackay, A., Green, S., Patterson, M., 2014. A soil change-based methodology for the quantification and valuation of ecosystem services from agro-ecosystems: a case study of pastoral agriculture in New Zealand. Ecol. Econ. 100, 119-129. http://dx.doi.org/10.1016/j.ecolecon.2014.02.008.

Doyen, E., Etienne, D., 2017. Ecological and human land-use indicator value of fungal spore morphotypes and assemblages. Veg. Hist. Archaeobotany 26, 357-367. http:// dx.doi.org/10.1007/s00334-016-0599-2.

Dreibrodt, S., Wiethold, J., 2015. Lake Belau and its catchment (northern Germany): a key archive of environmental history in northern central Europe since the onset of agriculture. The Holocene 25, 296-322.

Elbaz-Poulichet, F., Dezileau, L., Freydier, R., Cossa, D., Sabatier, P., 2011. A 3500-year record of hg and $\mathrm{Pb}$ contamination in a Mediterranean sedimentary archive (the Pierre Blanche Lagoon, France). Environ. Sci. Technol. 45, 8642-8647. http://dx.doi. org/10.1021/es2004599.

Enters, D., Dorfler, W., Zolitschka, B., 2008. Historical soil erosion and land-use change during the last two millennia recorded in lake sediments of Frickenhauser See, northern Bavaria, central Germany. The Holocene 18, 243-254. http://dx.doi.org/ $10.1177 / 0959683607086762$.

Etienne, D., Jouffroy-Bapicot, I., 2014. Optimal counting limit for fungal spore abundance estimation using Sporormiella as a case study. Veg. Hist. Archaeobotany 23, 743-749. http://dx.doi.org/10.1007/s00334-014-0439-1.

Etienne, D., Wilhelm, B., Sabatier, P., Reyss, J.-L., Arnaud, F., 2013. Influence of sample location and livestock numbers on Sporormiella concentrations and accumulation rates in surface sediments of Lake Allos, French Alps. J. Paleolimnol. 49, 117-127. http://dx.doi.org/10.1007/s10933-012-9646-x.

Faegri, K., Iversen, J., 1989. Textbook of Pollen Analysis, Revised by Faegri K, Kaland PE, Krzywinski K. J Wiley, New York.

FAO, 2006. Guidelines for Soil Description, 4, [rev.] ed. ed. FAO, Rome.

Ficetola, G.F., Pansu, J., Bonin, A., Coissac, E., Giguet-Covex, C., De Barba, M., Gielly, L., Lopes, C.M., Boyer, F., Pompanon, F., et al., 2015. Replication levels, false presences and the estimation of the presence/absence from eDNA metabarcoding data. Mol. Ecol. Resour. 15, 543-556.

Giguet-Covex, C., Arnaud, F., Poulenard, J., Disnar, J.-R., Delhon, C., Francus, P., David, F., Enters, D., Rey, P.-J., Delannoy, J.-J., 2011. Changes in erosion patterns during the Holocene in a currently treeless subalpine catchment inferred from lake sediment geochemistry (Lake Anterne, $2063 \mathrm{~m}$ a.s.1., NW French Alps): the role of climate and human activities. The Holocene 21, 651-665. http://dx.doi.org/10.1177/ 0959683610391320.

Giguet-Covex, C., Pansu, J., Arnaud, F., Rey, P.-J., Griggo, C., Gielly, L., Domaizon, I., Coissac, E., David, F., Choler, P., Poulenard, J., Taberlet, P., 2014. Long livestock farming history and human landscape shaping revealed by lake sediment DNA. Nat. Commun. 5. http://dx.doi.org/10.1038/ncomms4211.

Goldberg, E.D., 1963. Geochronology with 210Pb. In: Radioactive Dating, pp. 121-131.

Heiri, O., Lotter, A.F., Lemcke, G., 2001. Loss on ignition as a method for estimating organic and carbonate content in sediments: reproducibility and comparability of results. J. Paleolimnol. 25, 101-110.

Hole, F.D., 1961. A classification of pedoturbations and some other processes and factors of soil formation in relation to isotropism and anisotropism. Soil Sci. 91, 375-377.

Holling, C.S., 1986. The resilience of terrestrial ecosystems: local surprise and global change. In: Sustainable Development of the Biosphere. 14 (292À317).

Hošek, J., Pokorný, P., Prach, J., Lisá, L., Grygar, T.M., Knésl, I., Trubač, J., 2017. Late Glacial erosion and pedogenesis dynamics: evidence from high-resolution lacustrine archives and paleosols in south Bohemia (Czech Republic). Catena 150, 261-278. http://dx.doi.org/10.1016/j.catena.2016.11.022.

Ibañez, J.J., De-Albs, S., Bermúdez, F.F., García-Álvarez, A., 1995. Pedodiversity: concepts and measures. Catena 24, 215-232.

Jeanroy, E., 1983. Diagnostic des formes du fer dans les pédogénèses tempérées: évaluation par les réactifs chimiques d'extraction et apports de la spectrométrie Mossbauer. Université de Nancy I.

Jenny, H., 1941. Factors of Soil Formation-a Sytem of Quantitative Pedology. McGrawHill, New York.

Johnson, D.L., Watson-Stegner, D., 1987. Evolution model of pedogenesis. Soil Sci. 143, 349-366.

Krishnaswamy, S., Lal, D., Martin, J.M., Meybeck, M., 1971. Geochronology of lake sediments. Earth Planet. Sci. Lett. 11, 407-414. http://dx.doi.org/10.1016/0012-821X (71) $90202-0$

Larsen, I.J., Almond, P.C., Eger, A., Stone, J.O., Montgomery, D.R., Malcolm, B., 2014 Rapid soil production and weathering in the southern Alps, New Zealand. Science 343, 637-640. http://dx.doi.org/10.1126/science.1244908.

Le Quéré, C., Andrew, R.M., Canadell, J.G., Sitch, S., Korsbakken, J.I., Peters, G.P., Manning, A.C., Boden, T.A., Tans, P.P., Houghton, R.A., Keeling, R.F., Alin, S., Andrews, O.D., Anthoni, P., Barbero, L., Bopp, L., Chevallier, F., Chini, L.P., Ciais, P., Currie, K., Delire, C., Doney, S.C., Friedlingstein, P., Gkritzalis, T., Harris, I., Hauck, J., Haverd, V., Hoppema, M., Klein Goldewijk, K., Jain, A.K., Kato, E., Körtzinger, A., Landschützer, P., Lefèvre, N., Lenton, A., Lienert, S., Lombardozzi, D., Melton, J.R., Metzl, N., Millero, F., Monteiro, P.M.S., Munro, D.R., Nabel, J.E.M.S., Nakaoka, S., O'Brien, K., Olsen, A., Omar, A.M., Ono, T., Pierrot, D., Poulter, B., Rödenbeck, C., Salisbury, J., Schuster, U., Schwinger, J., Séférian, R., Skjelvan, I., Stocker, B.D., Sutton, A.J., Takahashi, T., Tian, H., Tilbrook, B., van der Laan-Luijkx, I.T., van der Werf, G.R., Viovy, N., Walker, A.P., Wiltshire, A.J., Zaehle, S., 2016. Global carbon budget 2016. Earth Syst. Sci. Data 8, 605-649. http://dx.doi.org/10.5194/essd-8605-2016.

Legros, J.-P., 2007. Les grands sols du monde. PPUR presses polytechniques.

Legros, J., Martini, I., 1992. Soils of Alpine mountains. In: Weathering, Soils and Paleosols, pp. 155-181.

Leveau, P., Segard, M., 2006. Le pastoralisme antique autour du col du Petit-SaintBernard. Alpis Graia, Archéologie sans frontières au col du Petit-Saint-Bernard, Seminario di chiusura, Aosta, 2-4 marzo 2006 153-161.

Malkiewicz, M., Waroszewski, J., Bojko, O., Egli, M., Kabala, C., 2016. Holocene vegetation history and soil development reflected in the lake sediments of the Karkonosze Mountains (Poland). The Holocene, 0959683615622546.

Massa, C., Bichet, V., Gauthier, É., Perren, B.B., Mathieu, O., Petit, C., Monna, F., Giraudeau, J., Losno, R., Richard, H., 2012. A 2500 year record of natural and anthropogenic soil erosion in South Greenland. Quat. Sci. Rev. 32, 119-130. http://dx. doi.org/10.1016/j.quascirev.2011.11.014.

McKeague, J., Brydon, J.E., Miles, N.M., 1971. Differentiation of forms of extractable iron and aluminum in soils. Soil Sci. Soc. Am. J. 35, 33-38.

Millet, L., Ortu, E., Miras, Y., Heiri, O., 2008. Les assemblages de chironomidae et les cortèges polliniques, outils de reconstitutions quantitatives des changements du climat Holocène: une approche croisée au col du Petit Saint Bernard.

Miras, Y., Millet, L., Guiter, F., Ponel, P., De Beaulieu, J.-L., Gozlar, T., 2006. Dynamique des écosystèmes et impact de l'homme dans le secteur du col du Petit Saint Bernard au cours de l'Holocène, in: Actes Du Séminaire de Clôture Du Programme INTERREG III A ALCOTRA 2000-2006: Alpis Graia. Archéologie sans Frontière Au Col Du Petit StBernard. Aoste. pp. 31-50.

Montagne, D., Cousin, I., Cornu, S., 2016. Changes in the pathway and the intensity of albic material genesis: role of agricultural practices. Geoderma 268, 156-164. http:// dx.doi.org/10.1016/j.geoderma.2016.01.019.

Montgomery, D.R., 2007. Soil erosion and agricultural sustainability. Proc. Natl. Acad. Sci. 104, 13268-13272.

Moulin, B., Rey, P.-J., 2008. Les séquences pédo-sédimentaires des versants du col du Petit Saint Bernard. In: Table Ronde Du GDR JURALP. COLLECTION EDYTEM Cahiers de Paléoenvironnement, Aix-en-Provence, France, pp. 191-206.

Mourier, B., 2008. Contribution de l'approche sédimentologique à la reconstitution de l'histoire des sols. In: Définition de traceurs pédologiques et application sur des sédiments lacustres de montagne (Maurienne, Savoie, France). Université de Savoie.

Mourier, B., Poulenard, J., Chauvel, C., Faivre, P., Carcaillet, C., 2008. Distinguishing subalpine soil types using extractible $\mathrm{Al}$ and $\mathrm{Fe}$ fractions and REE geochemistry. Geoderma 145, 107-120. http://dx.doi.org/10.1016/j.geoderma.2008.03.001.

Mourier, B., Poulenard, J., Carcaillet, C., Williamson, D., 2010. Soil evolution and subalpine ecosystem changes in the French Alps inferred from geochemical analysis of 
lacustrine sediments. J. Paleolimnol. 44, 571-587. http://dx.doi.org/10.1007/ s10933-010-9438-0.

Oldeman, L., 1994. The Global Extent of Soil Degradation. Soil Resilience and Sustainable Land Use. 9.

Pallmann, H., 1947. Pédologie et Phytosociologie. Comptes rendus de la Conférence de Pédologie Méditerranéenne. Springerpp. 3-36 (Editions AFES).

Pansu, J., Giguet-Covex, C., Ficetola, G.F., Gielly, L., Boyer, F., Zinger, L., Arnaud, F., Poulenard, J., Taberlet, P., Choler, P., 2015. Reconstructing long-term human impacts on plant communities: an ecological approach based on lake sediment DNA. Mol. Ecol. 24, 1485-1498.

Poulenard, J., Arnaud, F., Perrette, Y., Sabatier, P., Deline, P., Giguet-Covex, C., Bajard, M., Mourier, B., Quiers, M., Malet, E., Develle, A.-L., Fanget, B., Faivre, P., Dambrine, É., Chalmin, E., 2015. Organic geochemistry of soils and sediments: a key to describe the anthropocene? In: Collection EDYTEM - Sols et Matières Organiques: Mémoires et Héritages. Presented at the Sessions communes des 12ème journées d'Etude de Sols Sols en héritages et de la 2ème réunion des chercheurs francophones en géochimie organique, Laboratoire EDYTEM, Université de Savoie 30 juin - 4 juillet 2014, pp. 9-18.

Protz, R., MARTINI, I., Ross, G.J., Terasmae, J., 1984. Rate of podzolic soil formation near Hudson Bay, Ontario. Can. J. Soil Sci. 64, 31-49.

Puydarrieux, P., Kervinio, Y., Darses, O., 2016. EFESE - Evaluation Française des Ecosystèmes et des Services Ecosystémiques - Rapport intermédiaire.

Reimer, P.J., Bard, E., Bayliss, A., Beck, J.W., Blackwell, P.G., Bronk Ramsey, C., Buck, C.E., Cheng, H., Edwards, R.L., Friedrich, M., 2013. IntCal13 and Marine13 Radiocarbon Age Calibration Curves 0-50,000 Years Cal BP.

Rémy, B., Lempereur, O., Amandry, M., 2006. Les monnaies Antiques découvertes au col du Petit SAint Bernard (versants Français et Italien), in: Actes Du Séminaire de Clôture Du Programme INTERREG III A ALCOTRA 2000-2006: Alpis Graia. Archéologie sans Frontière Au Col Du Petit St-Bernard. Aoste. pp. 163-179.

Rey, P.-J., 2011. Réservoirs et systèmes d'irrigation dans les alpages du col du Petit Saint Bernard: vers l'identification de structures antiques. Les Cahiers du CRHIPA. pp. 354.

Rey, P.-J., Moulin, B., 2006. Occupations et circulations pré-romaines autour du Col du Petit-Saint-Bernard; méthode et premiers résultats d'une étude archéologique et sédimentaire de la montagne alpine. In: Projet Interreg IIIA, Seminario Di Chiusura. Musumeci SPA, pp. 77-118.

Rey, P.-J., Batigne-Vallet, C., Collombet, J., Delhon, C., Martin, L., Moulin, B., Oberlin, C., Poulenard, J., Robin, V., Thiebault, S., Treffort, J.-M., 2014. Approche d'un territoire de montagne: occupations humaines et contexte pédo-sédimentaire des versants du col du Petit-Saint-Bernard, de la Préhistoire à l'Antiquité. In: Senépart, I., Billiard, C., Bostyn, F., Praud, Y., Thirault, E. (Eds.), Méthodologie des recherches de terrain sur la Préhistoire récente en France. Nouveaux acquis, nouveaux outils, 1987-2012. Actes des premières Rencontres Nord-Sud de Préhistoire récente, Marseille, mai 2012. 73-71.

Rey, P.-J., Franc, O., Fudral, S., Moulin, B., Moulin, 2015. Le Cercle de pierres dressés du Col du Petit Saint-Bernard (Savoie - Val d'Aoste, 2188 m d'altitude) Nouvelles données de terrain et pistes d'interprétation. Société Valdôtaine de préhistoire et d'archéologie. pp. 163-190.

Reyss, J.-L., Schmidt, S., Legeleux, F., Bonté, P., 1995. Large, low background well-type detectors for measurements of environmental radioactivity. In: Nuclear Instruments and Methods in Physics Research Section A: Accelerators, Spectrometers, Detectors and Associated Equipment. 357. pp. 391-397.
Richter, D., 2007. Humanity's transformation of Earth's soil: Pedology's new frontier. Soil Sci. 172, 957-967.

Robbins, J.A., Edgington, D.N., 1975. Determination of recent sedimentation rates in Lake Michigan using Pb-210 and Cs-137. Geochim. Cosmochim. Acta 39, 285-304.

Sabatier, P., Dezileau, L., Briqueu, L., Colin, C., Siani, G., 2010. Clay minerals and geochemistry record from northwest Mediterranean coastal lagoon sequence: implications for paleostorm reconstruction. Sediment. Geol. 228, 205-217. http://dx.doi. org/10.1016/j.sedgeo.2010.04.012.

Sabatier, P., Poulenard, J., Fanget, B., Reyss, J.-L., Develle, A.-L., Wilhelm, B., Ployon, E., Pignol, C., Naffrechoux, E., Dorioz, J.-M., et al., 2014. Long-term relationships among pesticide applications, mobility, and soil erosion in a vineyard watershed. Proc. Natl. Acad. Sci. 111, 15647-15652.

Shand, C.A., Wendler, R., 2014. Portable X-ray fluorescence analysis of mineral and organic soils and the influence of organic matter. J. Geochem. Explor. 143, 31-42. http://dx.doi.org/10.1016/j.gexplo.2014.03.005.

Simonneau, A., Doyen, E., Chapron, E., Millet, L., Vannière, B., Di Giovanni, C., Bossard, N., Tachikawa, K., Bard, E., Albéric, P., Desmet, M., Roux, G., Lajeunesse, P., Berger, J.F., Arnaud, F., 2013. Holocene land-use evolution and associated soil erosion in the French Prealps inferred from Lake Paladru sediments and archaeological evidences. J. Archaeol. Sci. 40, 1636-1645. http://dx.doi.org/10.1016/j.jas.2012.12.002.

Stockmarr, J., 1971. Tablets with spores used in absolute pollen analysis. Pollen Spores 13, 615-621.

Stucki, J.W., Goodman, B.A., Schwertmann, U., 1988. Iron in Soils and Clay Minerals.

Taberlet, P., PRUD'HOMME, S.M., Campione, E., Roy, J., Miquel, C., Shehzad, W., Gielly, L., Rioux, D., Choler, P., Clément, J.-C., et al., 2012. Soil sampling and isolation of extracellular DNA from large amount of starting material suitable for metabarcoding studies. Mol. Ecol. 21, 1816-1820.

Talon, B., 2006. Analyses anthracologiques au col du Petit St-Bernard. Archéoanthracologie et pédoanthracologie., in: Actes Du Séminaire de Clôture Du Programme INTERREG III A ALCOTRA 2000-2006: Alpis Graia. Archéologie sans Frontière Au Col Du Petit St-Bernard. Aoste. pp. 51-58.

Tamm, O., 1922. Urn bestamning ow de organisk komponenterna i merkens gelkomplex. Medd. Slatens. Skogsforsokanst. 19. pp. 384.

Trimble, S.W., Mendel, A.C., 1995. The cow as a geomorphic agent-a critical review. Geomorphology 13, 233-253.

Vanwalleghem, T., Gómez, J.A., Infante Amate, J., González de Molina, M., Vanderlinden, K., Guzmán, G., Laguna, A., Giráldez, J.V., 2017. Impact of historical land use and soil management change on soil erosion and agricultural sustainability during the Anthropocene. Anthropocene 17, 13-29. http://dx.doi.org/10.1016/j.ancene.2017. 01.002 .

Willis, K.J., Braun, M., Sümegi, P., Tóth, A., 1997. Does soil change cause vegetation change or vice versa? A temporal perspective from Hungary. Ecology 78, 740-750.

Wilmshurst, J.M., McGlone, M.S., 2005. Origin of pollen and spores in surface lake sediments: comparison of modern palynomorph assemblages in moss cushions, surface soils and surface lake sediments. Rev. Palaeobot. Palynol. 136, 1-15. http://dx.doi. org/10.1016/j.revpalbo.2005.03.007.

WRB - FAO, 2014. World Reference Base for Soil Resources 2014 International Soil Classification System for Naming Soils and Creating Legends for Soil Maps. FAO, Rome.

Yaalon, D.H., Yaron, B., 1966. Framework for man-made soil changes-an outline of metapedogenesis. Soil Sci. 102, 272-277. 